\title{
Latino And Latina Critical Theory: An Annotated Bibliography
}

\author{
Jean Stefancic $\dagger$
}

\section{INTRODUCTION}

Latino/a critical scholarship, though largely ignored, has been around for a long time. One might say that its progenitor was Rodolfo Acuna, whose book Occupied America, ${ }^{1}$ originally published in 1972, is now in its third edition. Acuna was the first scholar to reformulate American history to take account of U.S. colonization of land formerly held by Mexico and how this colonization affected Mexicans living in those territories. His thesis has proven as powerful for Latinos as the potent theories of Derrick Bell have been in understanding the dynamics of race for blacks. ${ }^{2}$

It took the Chicano movement of the 1960 s and 1970 s finally to force examination of American society from a Latino perspective. Farmworker strikes, high school walkouts, and the Chicano Mobilization movement brought the troubles of this community to national attention, even more than did the Zoot Suit riots and forced deportations earlier in the century.

Copyright $(1997$ California Law Review, Inc.

$\dagger$ Research Associate, University of Colorado School of Law. I thank Ian Haney Lopez, Margaret Montoya, and Juan Perea for initial helpful suggestions, and Frank Valdes for his enthusiastic support of this project. To Richard Delgado, as always I am grateful for advice, encouragement, dishwashing, and inspiration. Gabriel Carter, Blaine Lozano Milne, Lance Oehrlein, and Kim Quinn provided insightful and unfaltering research assistance. For a forthcoming volume expanding on many of the themes of this bibliography, see The Latino Condition: A CRitical READER (Richard Delgado \& Jean Stefancic eds., forthcoming 1998). For earlier bibliographies of critical race theory, see Richard Delgado \& Jean Stefancic, Critical Race Theory: An Annotated Bibliography, 79 VA. L. Rev. 461 (1993); Richard Delgado \& Jean Stefancic, Critical Race Theory: An Annotated Bibliography 1993, A Year of Transition, 66 U. CoLo. L. REv. 159 (1995).

1. Rodolfo F. AcuÑa, Occupied America: A History of Chicanos (3rd ed. 1988).

2. See, e.g., Derrick Bell, Confronting Authority: Reflections of an Ardent Protester (1994); Derrick Bell, Faces at the Bottom of the Well: The Permanence of Racism (1992); Derrick Bell, Race, Racism and American law (3d ed. 1992). 
For a time, Reaganism and supply-side economics derailed the momentum of these and other progressive movements. Nevertheless, Chicano studies programs, created in response to student demands mainly in West Coast public universities, united a critical mass of scholars in sociology, political science, history, anthropology, literary criticism, and film studies. Latino studies slowly gained ground, although not in law. With the fall of the Berlin wall and demise of the Soviet empire, America's obsession with an external enemy refocused on domestic irritants, including activist minority groups and politically correct college programs. Immigration reform acts of 1965 and 1986 brought a substantial increase of new immigrants from Latin American countries. By the end of the 1980s their presence had become so visible as to begin creating another wave of retrenchment. English-only movements appeared, bilingual education came under fire, and conservatives began calling for immigration restriction. The riots in Los Angeles that followed the acquittal of the police officers who assaulted Rodney King focused media attention on tensions among blacks, Latinos, and Asians.

By then, the number of Latino/a law professors had finally risen to the point at which they could plausibly be described as a "crop"-i.e., more than a handful. Dissatisfied with both liberal and newer approaches to antidiscrimination law, Latino/a law professors began meeting in small groups, often as adjuncts to other meetings such as the Association of American Law Schools (AALS), Critical Race Theory workshops, or the Hispanic National Bar Association. They began writing articles, naming the new body of scholarship LatCrit Theory. A spin-off of Critical Race Theory, with which it remains allied, LatCrit Theory calls attention to the way in which conventional, and even critical, approaches to race and civil rights ignore the problems and special situations of Latino people-including bilingualism, immigration reform, the binary black/white structure of existing race remedies law, and much more. The emerging body of Latino/a critical legal scholarship now includes over one hundred law review articles and several books.

3. This statement is not without exception. See, e.g., Richard Delgado \& Vicky Palacios, Mexican Americans as a Legally Cognizable Class Under Rule 23 and the Equal Protection Clause, 50 Notre Dame L. Rev. 393 (1975); Gerald Lopez, Undocumented Mexican Migration: In Search of a Just Immigration Law and Policy, 28 UCLA L. REv. 615 (1981); Leo Romero et al., The Education of Chicano Students: A Study in Mutual Accommodation and Cultural Conflict, 5 N.M. L. REv. 177 (1975).

4. See, e.g., Michael Olivas, The Education of Latino Lawyers: An Essay on Crop Cultivation, 14 Chicano-Latino L. Rev. 117 (1994). 
This bibliography lists and annotates each of these, as well as a number of key books and essays from other disciplines, under a series of categories or headnotes corresponding to a major LatCrit theme or subject area. Although I have aimed to be as comprehensive as possible, I have not included works that seemed to duplicate an author's previous work, very short articles, or, for the most part, book reviews or essays. I also did not include articles or books, however meritorious, that fall within the liberal tradition or that simply argue that problems of race and discrimination will yield if we all try harder. Instead, I looked for works that offer novel, critical, or foundational analysis, works on whose insights future scholarship might build.

My methodology was as follows. I examined every article and book by a known LatCrit legal scholar published or coming to my attention before June 1997, reading footnotes and bibliographies for works that appeared frequently. I then examined these other works, as well as additional ones referred to in their footnotes and bibliographies, for possible inclusion in the database, and so on until the circle began to close. I read and examined novels, collections of essays, journals, and works of history, sociology, literary criticism, and ethnic studies. When the annotated bibliography was completed, I mailed it to every legal author for corrections and suggestions. I also requested that each author examine the entire bibliography and suggest additional articles and books that I had omitted. To be included, a work needed to address one or more of the following themes I deemed characteristic of critical Latino/a scholarship. The themes, and the numbering system ("headnotes") used in the bibliography, are as follows:

1. Critique of liberalism. Many Latino/a writers argue, expressly or implicitly, that liberalism fails to address the Latino condition. Other authors target a mainstay of liberal jurisprudence such as neutrality, objectivity, color blindness, or the inability to address group-based harms.

2. Storytelling/counterstorytelling and "naming one's own reality." Latino culture incorporates a long, rich tradition of storytelling. Though few actual stories are included in this bibliography, the collections of literary criticism herein annotated testify to the power of stories to reflect Latino culture. In addition, the stories often attempt to change the majoritarian mindset, which many Latino/a scholars consider a key obstacle to the recognition of injustice and implementation of racial reform. 
3. Revisionist interpretations of U.S. civil rights law and progress. Much of U.S. antidiscrimination law has not served the needs of Latinos. Not only has progress been halting, but court decisions and policy choices have been unreliable and wavering. Reparational civil rights law, based on a black/white paradigm and crafted to address historical injustice against African Americans, has not always worked as effectively for Latinos, especially those defined by multiple categories.

4. Critical social science. Historians describe the longtime effects on Latinos of living as a conquered people with ambiguous citizenship status. Sociologists and anthropologists reveal the hybridity of Latino people, exemplified in the concepts of mestizaje and double or multiple consciousness resulting from centuries of cultural blending and conflict.

5. Structural determinism. A number of Latino/a writers focus on ways in which the structure of culture or legal thought influences its content, in particular its tendency to maintain the status quo. Understanding these constraints results in working more effectively towards racial and other types of reform. Works addressing the way Western society differently racializes groups are placed here as well.

6. Intersectionality. Latina feminists, as well as other feminists of color, explore the intersectionalities of race, gender, class, and sexual orientation. Latinas focus particularly on another multiple oppression, stemming from being excluded from the women's movement and its agendas, as well as having to use color-based remedies based on the needs of African-American women.

7. Gender discrimination. Though gender discrimination is common to all women, some writers focus on a form particular but not unique to Latino culture-machismo (exaggerated masculinity). Works on domestic violence fall into this category, as do works on the role of color, poverty, lack of education, and Catholicism in subordinating women.

8. Latino/a essentialism. Does race-including the Latino race-exist except as a social construction? Does pan-Latinoism exist? Some writers address this question by asking what the appropriate unit of analysis is: Is the Latino community one, or many? How do middle, working class, and immigrant Latinos differ? Is language their only common trait? Are Latinos a diaspora, an ethnicity, or something else? 
9. Language and bilingualism. Spanish was spoken in the Southwest long before Anglos arrived and continues to be a unifying element in Latino communities throughout the United States. English-only movements attack bilingual education programs, ballots, and government forms. Debates rage about the value of voice and the legal status of language.

10. Separatism and nationalism. Though nationalism and calls for separatism flourished during the Chicano movement of the 1960 s and early 1970s, they played a lesser role later. Some LatCrit scholars are reviving these notions, however, arguing that preserving diversity and cultural integrity benefits all, not just Latinos/as.

11. Immigration and citizenship. How is the U.S. civil polity constituted, and where do Latinos fit within it? Recent referenda, like California's Proposition 187, focus attention on increasing numbers of immigrants, many of them Latino, who enter the United States legally or illegally. Latino/a legal scholars address questions, raised by nativists and others, of equitable distribution of jobs and benefits.

12. Educational issues. Latinos/as have long been concerned about representation in education at all levels, as well as increasing their numbers in the bar. A number of authors have begun to search for new approaches to learning style, clinical education, affirmative action, and critical pedagogy.

13. Critical international and human rights law. Some LatCrit scholars critique the state-centered, traditionally male-dominated model of international human rights law, which is grounded in Western European Enlightenment thought and incorporates the perspective of the colonizer.

14. Black/brown tensions. African Americans and Latinos, long-time allies in the civil rights movement, no longer work in coalition as closely as they once did. Not only do both groups suffer from the divide-andconquer tactics of white policy makers, they endure other tensions as well. Latinos/as question the essentialist urge that imposes civil rights remedies designed for blacks on the Latino community, while African Americans sometimes do not oppose restrictive immigration measures or English-only legislation. For their part, African Americans 
sometimes charge that Latinos ride on the coattails of the civil rights movement, while not doing the hard work. Both groups have begun to question how the other is racially defined and positioned.

15. Assimilationism and the colonized mind. Centuries of colonization by Western European countries have left a mark on third world cultures. Some writers explore the effect of dominance on the behavior and thought of the colonized, and offer strategies to overcome or subvert that influence.

16. Latino/a stereotypes. Stereotyping that which is different in order to tame its seemingly dangerous aspects is common to all societies, with stereotyping directed against people of color being the most virulent type. A number of works deal with images of Latinos/as in popular culture-movies, the media, literature, etc. Others use linguistic and cognitive theories to analyze and explore the role of stereotypes.

17. Criticism and response. Included are some of the more well-known critiques of Latino/a ethnic consciousness, most of them by outsiders to the movement. Other works incorporate responses to such criticism.

\section{ANNOTATED BIBLIOGRAPHY}

Acosta, Oscar "Zeta," The Uncollected Works (Ilan Stavans ed., 1996). (Themes 1, 2, 3, 5, 6, 9, 12).

Anthology of essays, letters, stories, and poems of charismatic Chicano lawyer and author of The Autobiography of a Brown Buffalo $^{5}$ (describing personal odyssey after leaving his job at a legal aid clinic in Oakland in 1967) and The Revolt of the Cockroach People ${ }^{6}$ (recounting the East Los Angeles high school walkout, strike, and trial and the 1970 Chicano Mobilization). Collection includes: Racial Exclusion, Una carta de Zeta al barrio, and the anarchist platform on which Acosta based his campaign for the office of Los Angeles County Sheriff in June 1970.?

5. Oscar Zeta Acosta, The Autobiography of a Brown Buffalo (1972).

6. Oscar Zeta Acosta, The Revolt of the Cockroach People (1973).

7. See also Ilan Stavans, Bandido: Oscar "Zeta" Acosta and the Chicano EXPERIENCE (1995) (revealing a complex Acosta who fearlessly fought against poverty, oppression, and racism in the Chicano community while exploring questions of personal identity). 
Acuña, Rodolfo F., Anything But Mexican: Chicanos in Contemporary Los Angeles (1996). (Themes 4, 5, 6, 7, 9, 11, 12, 14).

Explores racist nativism by examining its impact on Chicanos living in Los Angeles. Contrasts ways Euroamericans view Mexicans with ways Mexicans view themselves. Examines how complex issues of Chicano identity implicate race, class, national origin, and relations with other minorities. Evaluates successes Chicanos have registered in politics and with federal appointments. Shows how scholarship produced by conservative thinktanks influenced legislation to reduce taxes, which lowered the quality of education for Chicanos and closed opportunities for civil service jobs, and helped pass Proposition 187 in California. Discusses changes in the global economy aud the struggle to unionize poor workers iu the face of these changes. Examines the continued relationship between Chicanos and Mexico. Analyzes how the increased political influence of middle-class Chicanos influenced the passage of the North American Free Trade Agreement (NAFTA).

Acuña, Rodolfo F., A Community Under Siege: A Chronicle of Chicanos East of the Los Angeles River 1945-1975 (1984). (Themes 4, $8,10,12)$.

Asserts that common knowledge of East Los Angeles comes from shallow media stereotypes with the result that little is known about the community's real history or the special economic interests that shape its destiny. Chronicles the concerns of its residents as reflected in two community weekly newspapers, the Eastside Sun and the Belvedere Citizen, from 1945-1975. Shows how downtown Los Angeles business interests exercised power over East Los Angeles by controlling land use, particularly urban renewal, rezoning, and freeway construction. Covers the development of the Chicano movement, as well as brown/black competition for federal funding, and concerns about immigration and bilingual education. Includes comprehensive list of articles published in the newspapers, suggestions for further research projects, and bibliographic sources.

Acuña, Rodolfo F., Occupied America: A History of Chicanos (3rd ed. 1988). (Themes $1,3,4,5,6,7,10,11,15,16)$.

Shows how U.S. invasions of Texas (1836) and Mexico (18451848) resulted in a legacy of hatred and violence toward Mexicans. Describes nineteenth-century conquest and colonization of Texas, New Mexico, Arizona, and Colorado that maintained Anglo control, privileged commercial interests, glorified the brutality of the Texas 
Rangers, and justified discrimination and terrorism against Mexican Americans. Examines how the expansion of agribusiness, mining, and industry and the shrinkage of the labor pool, diminished by the Chinese Exclusion Act, caused U.S. capitalists to create an underclass by recruiting Mexicans for cheap labor without adequate access to housing, health care, education, or the right to unionize. Describes how Depression-era sentiment against Mexicans resulted in massive deportations and how the interplay of U.S. business interests, changes in the labor market, and nativist sentiments continue to limit economic opportunities for Mexicans today. Explores the development and influence of the Chicano movement, the rise of the Hispanic middle class, and offers predictions about the future.

Almaguer, Tomás, Racial Fault Lines: The Historical Origins of White Supremacy in California (1994). (Themes 1, 3, 4, 5, 6, 7, 16).

Describes the racialization of three major groups in CaliforniaMexican Americans, Native Americans, and Asian Americansduring the nineteenth century. Shows how the black/white model of race relations gave way to the incorporation of class and culture, resulting in a more complex form of white supremacy than that which appeared in other parts of the United States. Examines how European American perceptions of the groups' cultural attributes afforded each group a place on the hierarchical ladder of acceptability and differential access to rewards and privileges that whites wanted to keep for themselves. Discusses implications of this social ordering for understanding relations among groups in California today.

Anzaldúa, Gloria, Borderlands/La Frontera: The New Mestiza (1987). (Themes 2, 4, 8, 15).

Experimental autobiography that argues against the patriarchy of Chicano culture and advocates a multi-dimensional approach to identity employing the border (la frontera) as a metaphor. The "borderlands" become a space for celebrating personal and cultural complexity, incorporating contradiction and ambiguity, also explored by other south Texas writers and artists (Rolando Hinojosa, Pat Moro, Tomás Rivera). Critiques multinational capitalism, especially Anglo agribusiness, which has commodified and privatized the physical borderlands of the Southwest and displaced the communal life of Chicanos. 
Arriola, Elvia R., Faeries, Marimachas, Queens, and Lezzies: The Construction of Homosexuality Before the 1969 Stonewall Riots, 5 Colum. J. Gender \& L. 33 (1995). (Themes 6, 16).

Examines moral, medical, and popular attitudes about sex, gender, race, and class to show how society viewed homosexuals as a threat to the American way of life and often sanctioned violent methods of law enforcement to rid itself of gays and lesbians. Retells the story of the Stonewall Riots, from a minority critical perspective, highlighting the role of black and Puerto Rican drag queens in triggering the New York Police Department's violent raid of a gay bar in New York City in 1969. Shows contrast between political activism of pre-Stonewall largely closeted white middle-class gay world and that of highly visible black, Latino/a, transgendered, and working class gays and lesbians. Argues that the radically diverse origins of the lesbian/gay/bi civil rights movement, often ignored by white middle-class organizers, deserve recognition for exposing the complexity of oppression, prejudice, and victimization.

Arriola, Elvia R., Gendered Inequality: Lesbians, Gays, and Feminist Legal Theory, 9 Berkeley Women's L.J. 103 (1994). (Themes 1, 5, 6).

Critiques traditional antidiscrimination law, showing that groupbased and individual-regarding models, as well as lesbian legal theory, mandate use of arbitrary, discrete, and hierarchical categories to address inequality issues. Argues that these models and the intersectionality model (which combines traditionally recognized categories) do not fully address discrimination directed against lesbians, gays, and others, such as Latinos/as, with complex social identities. Advocates a "holistic/irrelevancy" model that enriches traditional models with awareness of multiple traits and stereotypes about social groups in order to achieve a more subtle analysis of oppression.

Arriola, Elvia R., "What's the Big Deal?" Women in the New York City Construction Industry and Sexual Harassment Law, 1970-1985, 22 Colum. Hum. Rts. L. Rev. 21 (1990). (Themes 1, 6, 7).

Traces the development of sexual harassment law from 1970 to 1985 , arguing that advances stemmed mainly from feminist activism and the predominantly white middle-class women's movement. Describes the reemergence of women in the U.S. work force especially in nontraditional jobs in the construction industry. Examines how issues of class, race, ethnicity, and sexual orientation continue to complicate the lives of blue-collar tradeswomen. Questions the 
ability of sexual harassment law to address complaints of women in the blue-collar sector if institutional and popular resistance prevail.

Austin, Regina \& Michael Schill, Black, Brown, Poor \& Poisoned: Minority Grassroots Environmentalism and the Quest for Eco-Justice, 1 Kan. J.L. \& Pub. Pol'y 69 (1991). (Themes 1, 4).

Points out that poor black and brown communities bear a disproportionate amount of environmental risk, including exposure to pesticides, herbicides, lead poisoning, and other pollution. Calls for the development of a grassroots environmental movement that is antiracist and antibourgeois and focúses more on political and economic roots of environmental oppression rather than romantic notions of wilderness ideals.

Aztlán: Essays on the Chicano Homeland (Rudolfo A. Anaya \& Francisco Lomeli eds., 1989). (Themes 2, 10).

Explores the Aztec origin of the legend of Aztlan and its present day artistic, social, and political ramifications. Shows the importance of Aztlan as a mythical ideal embracing nostalgia and utopian possibility for contemporary Chicano identity and cultural cohesion. Essays include historical, anthropological, and cultural analyses, as well as symbolic interpretations in literature and myth by Luis Leal, Jorge Klor de Alva, Ramón A. Gutiérrez, Gloria Anzaldúa, Alurista, and others.

Barrera, Mario, Race and Class in the Southwest: A Theory of Racial Inequality (1979). (Themes 4, 5, 6, 11).

Addresses Chicano inequality in the Southwest from the nineteenth century to the present, describing how the establishment of a subordinate labor force created the foundation upon which present day inequality persists. Examines the state's role in protecting capitalist interests and regulating the labor supply. Analyzes deficiency, bias, and structural discrimination theories of racial equality. Combines insights of Marxist theories of race and class structure with an internal colonialism approach to explain the subordinated status of Mexican Americans in the Southwest.

Behar, Ruth, Translated Women: Crossing the Border with Esperanza's Story (1993). (Themes 2, 4, 6, 7, 8, 15).

Presents the autobiographical story of a Mexican-Indian woman and explains how the task of feminist ethnography (like that of the 
legal services lawyer) contains inherent dangers, ironies, and an inversion of the usual power relationship between writer and subject. Demonstrates how the process of producing a life history may colonize by reducing the subject to a "text," just as it transforms the ethnographer herself from a listener to a storyteller. Points out that the feminist anthropologist must present her subject's life history in both novelistic and dialogic styles, as the relationship of ethnographic subject and ethnographer is both preserved and obliterated in the telling.

Bender, Steven W., Consumer Protection for Latinos: Overcoming Language Fraud and English-Only in the Marketplace, 45 Am. U. L. Rev. 1027 (1996). (Themes 5, 9).

Points out that unscrupulous merchants often take advantage of Spanish-speaking and other immigrant groups. Argues that current controls and doctrines such as fraud and duress are often insufficient for non-English speaking consumers preyed upon in this fashion. Discusses possible solutions, including the notion that the English-only marketplace is, per se, fraudulent.

Berk-Seligson, Susan, The Bilingual Courtroom: Court Interpreters in the Judicial Process (1990). (Themes 1, 9).

Examines the role of the interpreter in the judicial process, showing that Spanish is the language most frequently translated. Argues that translation puts non-English speaking litigants at a disadvantage because of the inability of some interpreters to translate nuance and idiom, with the result that the tone and meaning of the testimony are changed. Points out the deficiencies of a legal system wherein most non-English speaking persons are not provided free court interpretation services in civil cases, and, because of the lack of financial resources, are forced to use bilingual friends who often do a poor job of interpreting testimony. Expands on her article "The Importance of Linguistics in Court Interpreting."8

Between Borders: Essays on Mexicana/Chicana History (Adelaida R. DeI Castillo ed., 1990). (Themes 4, 6, 7).

Contains essays by Chicana/o scholars examining theoretical issues such as historical materialism that bear on Chicana history. Includes other works focusing on labor history, examining the exploitation of

8. Susan Berk-Seligson, The Importance of Linguistics in Court Interpreting, 2 LA RAzA LJ. 14 (1988). 
Chicana workers in the United States and Mexico, and the difficulties they encounter in trying to improve their economic conditions. Describes the sexism and racism directed against Chicanas by society and political movements. Discusses research sources and methods.

Beyond Stereotypes: The Critical Analysis of Chicana Literature (María Herrera-Sobek ed., 1985). (Themes 2, 6, 7, 15, 16).

Collects articles from the first conference on Chicana writers presented at the symposium "New Perspectives in Literature: Chicana Novelists and Poets," held at the University of California, Irvine, May, 1982. Essays examine the themes, voices, and processes of Chicana short-story writers, novelists, and poets in their engagement with issues of silencing, assimilation, intersectionality, stereotyping, humor, and machismo, as well as their new perspectives on myths and figures such as La Malinche.

Blacks, Latinos, and Asians in Urban America: Status and Prospects for Politics and Activism (James Jennings ed., 1994). (Themes 3, 4, 11, 14).

Explores how communities of color relate to each other politically, and assesses problems in developing coalitions for progressive social action. Focuses on relations among blacks, Latinos, and Asians, examining the origins of and factors that shape the political agendas of Latinos and blacks, and the pros and cons of political coalitions between the two groups. Presents studies of three cities-Washington, D.C., Miami, and Los Angeles-where coalitions among minorities affected urban politics. Includes excerpts from a speech by Chicano activist Daniel Osuna, discussing historical parallels in the Chicano and black communities' political struggles for social equality in the United States.

Blauner, Robert, Racial Oppression in America (1972). (Themes 1, 3, 4, $5,6,10,14,15)$.

Critiques framework derived from European social theory by sociologists after World War $\Pi$, which ironically assumed the declining importance of race and ethnicity at the very time when U.S. social scientists most needed theories to understand it. Rebuts the immigrant/assimilationist models advanced by Glazer and Moynihan and proposes an analysis of the structural components of racial oppression, asserting that race cannot be reduced to class nor racism to irrational beliefs. Argues that internal colonization of people of color in the United States created distinctive histories of repression 
distinguishing racial minorities from each other and from European ethnic groups. Shows how 1960s-era policies divided blacks and browns and set them against each other. Posits that Chicanos are more averse to Anglo culture and more pessimistic about receiving justice at its hands than blacks. Lauds the complexity and diversity of Chicano literature. Concludes with case histories of institutional racism based on the author's experiences as a sociologist. Represents a classic work in sociology of race.

Bosniak, Linda S., Opposing Prop. 187: Undocumented Immigrants and the National Imagination, 28 Conn. L. Rev. 555 (1996). (Themes 1, 5, 11, 12).

Shows how most liberals argue against Proposition 187 (a virulently nativist California initiative) on the basis of side issues-for example, that it will poorly serve its own state objectives, such as saving money; that it is a distastefully xenophobic measure; or that it will create certain social pathologies, such as turning teachers into immigration cops- while virtually ignoring the central issue that the anti-immigrant measure is fundamentally unjust to undocumented immigrants. Argues that much leftist thought endorses protectionism or tacitly accepts the nation-state as the unit of social analysis, rendering it difficult to deal with injustice that takes the form of excluding groups from U.S. society in the first place. Remedying this normative nationalism will require an effort of the imagination, without which it will be impossible to address fully the reality of the undocumented.

Bracamonte, José A., Foreword: Minority Critiques of the Critical Legal Studies Movement, 22 Harv. C.R.-C.L. L. Rev. 297 (1987). (Themes 1, 3).

Reflects on the promise and frustration that critical legal studies holds for minority scholarship and politics. Praises critical legal studies for a generally progressive agenda and for developing useful tools such as the indeterminacy thesis, legitimation, and the critique of rights. Nevertheless, warns that without additional effort, leftist organizations may fail to account fully for the historical and existential needs of people of color, and instead adopt organizational practices antithetical to those needs. Gives examples of such failings and shows how critical legal studies may address them by incorporating the perspectives of the marginalized. Articles by Richard Delgado, Mari Matsuda, Patricia Williams and Harlon Dalton follow. 
Breaking Boundaries: Latina Writing and Critical Readings (Asunción Horno-Delgado et al. eds., 1989). (Themes 2, 6, 7, 15).

One of the first collections of Latina literary criticism to present studies of Chicana, Puertorriqueña, and Cubana writers in one volume. Focuses on works that have been largely unrecognized by the literary establishment in order to make this literature more visible and accessible. Personal narratives (testimonios) begin each section, followed by critical essays by leading writers including Cherrie Moraga, Sandra Cisneros, Ana Castillo, Evangelina Vigil, and others. Includes introductory essay on Latina literary discourse.

Burciaga, José Antonio, Drink Cultura: Chicanismo (1993). (Themes 2, $6,8,9,11,15,16)$.

Examines the relationship of the Chicano to his Mexican roots and to U.S. culture in a series of sly short essays about historical events and the author's own personal experiences. Recounts the racism faced by Chicanos and tensions faced by Mexican Americans who are not thought of as fully American by the dominant society and are regarded as foreign by Mexicans. Contrasts how the United States and Mexico view issues of race, gender, and class, and the relationship of Chicanos to both cultures.

Cameron, Christopher David Ruiz, How the García Cousins Lost Their Accents: Understanding the Language of Title VII Decisions Approving Speak-English-Only Rules as the Product of Racial Dualism, Latino Invisibility, and Legal Indeterminacy, 85 Calif. L. Rev. 1347 (1997), 10 La Raza L.J. 261 (1997). (Themes 3, 9).

Discusses English-only stories of the cousins García: Hector, as reported in Garcia v. Gloor; ${ }^{9}$ Priscilla, as reported in Garcia v. Spun Steak Co., ${ }^{10}$ and the fictional Yolanda of Julia Alvarez' novel How the Garcia Girls Lost Their Accents, ${ }^{1}$ showing that none of the cases stated a claim for national origin discrimination. Examines how Title VII's black/white binary categories fail to address discrimination against bilingual workers. Demonstrates how the majority culture's ignorance of Spanish, as well as their perceptions of Latinos/as in subordinate roles, render Latinos/as invisible and their claims illegitimate. Shows how the definition of national origin discrimination varies from judge to judge, and is unreliable. Advocates that courts

\footnotetext{
9. 618 F.2d 264 (5th Cir. 1980).

10. 998 F.2d 1480 (9th Cir. 1993).

11. Julia Alvarez, How the García Girls Lost Their Accents (1991).
} 
and litigants redefine concepts of national origin discrimination to afford justice to bilingual speakers.

Chang, Robert S. \& Keith Aoki, Centering the Immigrant in the Inter/National Imagination, 85 Calif. L. Rev. 1395 (1997), 10 La Raza L.J. 309 (1997). (Theme 11).

Focusing on the Asian-American experience, examines the interplay among the ideas of the immigrant, the state, and the border in a racialized world. Shows how crude understandings of the border as a bright line facilitate nativism and violence and serve majoritarian political and economic interests, such as the availability of cheap labor. They also reinforce and are reinforced by binary understandings of race as a legal concept so that we come to think the only important racial categories are black and white. The fluid quality that Asian and Latino immigrants represent can serve as a useful metaphor for thinking more productively and flexibly about issues of race, power, and difference.

Chavez, Linda, Out of the Barrio: Toward a New Politics of Hispanic Assimilation (1991). (Theme 17).

Argues that any monocultural view of Hispanics ignores racial and ethnic diversity of the Latino community and takes no account of class analysis. Contains express and implied criticism of several tenets of leftist and LatCrit thought, including that: bilingualism is valuable, total assimilation is to be resisted, affirmative action and diversity are unqualified goods, Latinos are disadvantaged as are African Americans, and the true voice of the Latino community is a rebellious one.

Cherena Pacheco, Yvonne M., Latino Surnames: Formal and Informal Forces in the United States Affecting the Retention and Use of the Maternal Surname, 18 T. Marshall L. Rev. 1 (1992). (Themes 5, 7).

Argues that although law no longer prohibits using the Spanish style surname, which consists of both fraternal and maternal surnames, strong cultural and bureaucratic pressures encourage Latinas to drop maternal surnames. Concludes that this practice causes a loss of identity to Latinas and reinforces the inferiority of Latino culture. Maintains that keeping both fraternal and maternal surnames better represents feminist ideology than the recent practice of not taking a spouse's name after marriage, because a feminist who does not take her spouse's name still retains her father's name, whereas under the Spanish approach the mother's name is preserved. Asserts that 
government and society should accommodate the Spanish style surname and that Latinas should insist on this accommodation.

Chicana Creativity and Criticism: New Frontiers in American Literature (María Herrera-Sobek \& Helena María Viramontes eds., rev. ed. 1996). (Themes 2, 6, 7, 15).

Collects Chicana literature and literary criticism presented at the second conference on Mexican-American women's literature held at the University of California at Irvine, April 22, 1987. Argues that Chicana writers, like their feminist and black-American colleagues, are expanding the frontier of American literature, challenging the institutionalized canon, and infusing new blood and ideas into that field.

Chicana Lesbians: The Girls Our Mothers Warned Us About (Carla Trujillo ed., 1991). (Themes 2, 6, 7).

Collects articles, essays, and poetry of Chicana lesbians that describe the difficulties of fitting into two worlds, neither of which is fully accepting. Argues that these writers must create or modify spirituality and family by altering traditional concepts that their very existence upsets. Examines life, desire, color, and struggle in the experience of Chicana lesbians.

Chicana Voices: Intersections of Class, Race, and Gender (Teresa Cordóva et al. eds., 1990). (Themes 4, 6, 7, 16).

Proceedings of the 1984 National Association for Chicano Studies twelfth annual conference held in Austin, Texas. All papers address issues of sexism previously raised by Chicanas at the 1982 meeting and examine labor and politics; language, literature and the arts; research methods; higher education; and problems of gender inequality as they relate to Chicanas.

Chicana (W)rites on Word and Film (María Herrera-Sobek \& Helena María Viramontes eds., 1995). (Themes 2, 6, 7, 16).

Collects Chicana poetry, prose, and film criticism presented at the third conference on creative works of Chicanas held at the University of California, Irvine in 1990. Explores feminist Chicana perspectives on social topics such as racism, poverty, immigrant discrimination, and domestic violence, and the challenges of being subject to racial and gender discrimination. Describes the progress 
Chicana filmmakers have made and obstacles encountered in obtaining funding.

Chicanas in the 80's: Unsettled Issues (Mujeres en Marcha ed., 1983). (Themes 6, 7).

Highlights proceedings of a panel organized by Mujeres en Marcha (U.C. Berkeley) at the 1982 National Association for Chicano Studies tenth annual conference in Tempe, Arizona. Addresses issues of gender inequality in the Association and in higher education generally, and how the particular concerns of Chicanas differ from those of Chicanos and white women. Represents an important early manifesto addressing sexism toward Chicanas in the academy.

Chicanas/Chicanos at the Crossroads: Social, Economic, and Political Change (David R. Maciel \& Isidro D. Ortiz eds., 1996). (Themes 1, 4, $6,8,9,11)$.

Assesses the Chicana/o experience through the writings of Chicana/o social scientists with emphasis on the 1980s through the present. Shows the impact that increasing numbers of Chicanos/as will have on the United States and argues that this trend should be accommodated rather than resisted. Examines the backlash Chicano and other Latino groups have experienced as a result of increased immigration. Analyzes how the lack of programmatic foresight prevented the 1980 s from becoming the "Decade of the Hispanic," when it was predicted that Latinos and whites would become economic equals. Criticizes the fragmentation of the Chicano political movement in the 1980 s when some Chicanos supported agendas such as the English-only movement. Argues that although Chicano families historically valued education as a way to escape poverty, Republican admimistrations have alleged the opposite. Concludes with the difficulties Chicanas encounter when trying to voice their opinions in the feminist movement.

Chicanos and Film: Representation and Resistance (Chon A. Noriega ed., 1992). (Themes 2, 6, 15, 16).

Examines portrayals of Chicanos/as in the cinema via essays by prominent Chicano/a academics, critics, and artists. Contrasts the stereotypical portrayals of Chicanos and Latinos in traditional American and Mexican commercial films with their treatment in films made by Latino filmmakers in the 1970 s as part of the Chicano rights movement. Of particular interest to legal scholars is 
Carl Gutiérrez-Jones' essay, "Legislating Language: The Ballad of Gregorio Cortez and the English Language Amendment," which examines issues surrounding language translation in criminal trials, including who should bear the financial responsibility for it.

Colloquium: International Law, Human Rights, and LatCrit Theory, 28 U. Miami Inter-Am. L. Rev. 177 (1997). (Themes 1, 2, 5, 6, 8, 11, 13).

Proceedings of the third colloquium of the Law Professors Section of the Hispanic National Bar Association, held in Miami in October 1996. Articles address three generations of international human rights law: civil and political rights; economic, social, and cultural rights; and solidarity rights. Contributors include Elizabeth $M$. Iglesias, Celina Romany, Berta E. Hernández-Truyol, Elvia R. Arriola, Kevin R. Johnson, Enid Trucios-Haynes, José E. Alvarez, Enrique R. Carrasco, Adrien Katherine Wing, Natsu Taylor Saito, Ileana M. Porras, and Raul M. Sanchez.

Colloquium: LatCrit Theory: Naming and Launching a New Discourse of Critical Legal Scholarship, 2 Harv. Latino L. Rev. 1 (forthcoming 1997). (Themes $1,3,5,9,11,12,14,15)$.

Proceedings of the second colloquium of the Law Professors Section of the Hispanic National Bar Association, held in La Jolla, California in May 1996. Contributors include Robert S. Chang, Ian F. Haney López, Berta E. Hernández-Truyol, Kevin R. Johnson, George A. Martinez, Margaret E. Montoya, Rachel F. Moran, Laura Padilla, Juan F. Perea, Francisco Valdes, and Stephanie M. Wildman.

Colloquium: Representing Latina/o Communities: Critical Race Theory and Practice, 9 La Raza L.J. 1 (1996). (Themes 6, 8, 9, 11, 12, 13).

Proceedings of the first colloquium of the Law Professors Section of the Hispanic National Bar Association, held in San Juan, Puerto Rico in October 1995. Articles and comments by Francisco Valdes, Leslie E. Espinoza, Juan F. Perea, Angel R. Oquendo, Celina Romany, Robert S. Chang, Deborah A. Ramirez, and Berta E. Hernández-Truyol.

Crawford, James, Hold Your Tongue: Bilingualism and the Politics of "English Only" (1992). (Theme 9).

Traces the history of ethnic tensions in the United States, showing how ethnic intolerance today is unique in that it focuses on language and apocalyptically links bilingualism with an alleged erosion of 
morality, unity, and U.S. nationhood. Seeks to show that language choice is legally a matter of group rights, of collective selfdetermination in a historically "ethnic democracy," as well as a matter of freedom of expression. Argues that the crucial policy issue is how to address bilingualism and changing demographics in the United States in a manner that balances freedom from language discrimination with efforts to overcome linguistic barriers in a democratic context. Concludes that the English-only movement rests on the fallacy that U.S. identity and ethnic harmony may be coerced by means contrary to the founding principles of the United States.

Criticism in the Borderlands: Studies in Chicano Literature, Culture, and Ideology (Héctor Calderón and José David Saldívar eds., 1991). (Themes 2, 5, 6, 7, 8, 11, 16).

Presents various ideological perspectives on Chicano/a critical theory ranging from ethnographic to postmodernist, from Marxist to feminist, from New Historicist to cultural materialist. Intended to raise awareness of historical and cultural interdependence of the Northern and Southern American hemispheres. Essays address institutional studies and the literary canon; representations of the Chicano/a subject regarding race, class, and gender; studies of genre, ideology, and history; and aesthetics of the border. Includes a selected annotated bibliography of contemporary Chicano/a literary criticism.

Darder, Antonia, The Politics of Biculturalism: Culture and Difference in the Formation of Warriors for Gringostroika and The New Mestizas, in Culture and Difference: Critical Perspectives on the Bicultural Experience in the United States 1 (Antonia Darder ed., 1995). (Themes $1,5,6,8,15)$.

Examines how bicultural people view their identity and ethnicity and how their experiences shape their cultural construction. Analyzes the impact of colonization and decolonization in the development of cultural consciousness, and shows how hybridity gives rise to border culture as articulated in the writings of Gloria Anzaldúa and Guillermo Gómez-Peña. Explores how the media distort social perceptions of subordinated groups. Urges reexamination of the concept "race relations," which implicitly defines race as biological, without accounting for the ways racism is manifested in class and political conflict. Argues for solidarity among subordinate groups to counter the dominant culture. 
Davis, Marilyn P., Mexican Voices/American Dreams: An Oral History of Mexican Immigration to the United States (1990). (Themes 2,11).

Examines the significance of el norte in the lives of Mexicans through the stories of legal and illegal immigrants and the families left behind. Shows how Mexican immigration patterns are inexorably tied to the need for labor in the United States. Describes the role of el coyote (border crossing guide). Highlights the dilemma that Mexico's best and brightest, those Mexico needs most to build up its economy and country, are fleeing north. Demonstrates that immigration will continue, driven by economic conditions in both countries, changing both the immigrants and American culture in the process.

De León, Arnoldo, They Called Them Greasers: Anglo Attitudes Toward Mexicans in Texas, 1821-1900 (1983). (Themes 4, 11, 16).

Analyzes white attitudes about Mexicans in Texas in the nineteenth century, including beliefs whites held, the roots of these beliefs, and how they became sanctioned in white culture. Maintains that whites, as a result of ethnocentrism and racism, believed that Americans were of superior stock to Mexicans in Texas (Tejanos), thereby justifying an elevated place for whites and a subservient one for Mexicans, deemed fit only for menial work benefiting whites. Seeks to counter biased depictions of Mexicans and chauvinistic attitudes of Anglo Texans put forward by earlier historians such as Walter Prescott Webb. Concludes that while some of the earlier stereotypes of Mexicans have disappeared, the common, and perhaps most prejudicial attitudes of whites towards Mexicans were valorized and institutionalized in the culture.

Delgado, Richard, Affirmative Action as a Majoritarian Device: Or, Do You Really Want to Be a Role Model?, 89 Mich. L. Rev. 1222 (1991). (Themes 1, 12, 17).

Questions the role-model argument for affirmative action, and affirmative action itself, as devices aimed at serving majoritarian interests more than those of the minority. Urges that professionals of color decline the role-model assignment, which entails adhering to white norms of decorum, dress, and behavior, and instead opt for more authentic relationships with their communities. 
Delgado, Richard, The Ethereal Scholar: Does Critical Legal Studies Have What Minorities Want?, 22 Harv. C.R.-C.L. L. Rev. 301 (1987). (Themes 1,5).

Lauds Conference on Critical Legal Studies for a generally progressive agenda and politics, but notes organizational and conceptual deficiencies in its treatment of race. Observes that the idealism inherent in much of critical legal studies thought is less attractive to communities of color, whose chains are largely material, and that its positive program of deformalized, decentralized social organization would leave disempowered groups even more exposed than they are now. Suggests that progressive movements embrace instead a "confrontation" theory of antidiscrimination that would confront racism directly, instead of indirectly or through utopian reorganization.

Delgado, Richard, The Imperial Scholar: Reflections on a Review of Civil Rights Literature, 132 U. Pa. L. Rev. 561 (1984). (Themes 1, 12).

Discusses treatment of black, Latino, and other scholars of color by mainstream civil rights authors. Finds that most fail to cite or take account of the work and ideas of minority scholars, resulting in distortions and omissions in the body of legal theory dealing with race and ethnicity. Urges that mainstream scholars check these practices and begin tempering their domination of the inner circles of civil rights writing.

Delgado, Richard, The Imperial Scholar Revisited: How to Marginalize Outsider Writing, Ten Years Later, 140 U. Pa. L. Rev. 1349 (1992). (Themes 1, 12).

Updates earlier article, examining how citation practices of mainline civil rights scholars have changed in intervening years. Finds that exclusion of voices of color is less overt than before, but continues. Describes mechanisms by which white male scholars continue to marginalize scholars of color and women. Concludes: "All discourse marginalizes."

Delgado, Richard, Minority Law Professors' Lives: The Bell-Delgado Survey, 24 Harv. C.R.-C.L. L. Rev. 349 (1989). (Theme 12).

Reports and comments on a survey of professors of color at U.S. law schools on workload, job satisfaction, stress, opportunities for advancement, relations with colleagues, and support from their institutions. Finds high levels of stress, exclusion from informal 
information networks, dissatisfaction with work environment, and doubts as to whether respondents would remain long at their jobs.

Delgado, Richard, Recasting the American Race Problem, 79 Calif. L. Rev. 1389 (1991). (Theme 1).

Reviews and praises Roy Brooks' Rethinking the American Race Problem, ${ }^{12}$ but points out that books in the liberal mold contain defects that can be remedied only by resorting to critical race theory's insights. Argues that the principle of formal equal opportunity, which Brooks urges be reclaimed by divesting it of recent baggage, cannot easily redress racism and indeed may unwittingly promote it. Argues that racism is the norm in our society and that formal equality will only single out and punish highly visible deviations from a racist status quo.

Delgado, Richard, The Rodrigo Chronicles: Conversations About America and Race (1995). (Themes 1, 2, 4, 5, 6, 10, 11).

Contains eight Chronicles and a conclusion, all taking the form of conversations between "Rodrigo," a fictional black-Latin foreign law school graduate, and "the Professor," an elderly American law professor who teaches civil rights. Topics include: immigration and deportation; law and economics; the role of love in antidiscrimination theory and practice; white-collar and street crime; and the operation of legal rules in perpetuating and confining racism.

Delgado, Richard, Rodrigo's Chronicle, 101 Yale L.J. 1357 (1992). (Themes 1, 2, 10).

Sets forth a conversation between Rodrigo and the Professor dealing with affirmative action, operation of the legal hiring market, and the role of outsider thought in arresting cultural stasis and decline in the industrialized West.

Delgado, Richard, Rodrigo's Fifteenth Chronicle: Racial Mixture, Latino-Critical Scholarship, and the Black-White Binary, 75 Tex. L. Rev. 1181 (1997). (Theines 1, 2, 5, 10, 15).

Reviews All Rise: Reynaldo G. Garza, The First Mexican American Federal Judge, by Louise N. Fisch (1996). Argues that the black/white binary operates in concert with other social forces to subordinate Latinos/as and that, unless challenged directly, generates

12. Roy Brooks, Rethinking the American Race Problem (1990). 
a powerful pressure toward assimilation on the part of the oppressed, and further marginalization on the part of elite decisionmakers.

Delgado, Richard, Rodrigo's Fourteenth Chronicle: American Apocalypse, 32 Harv. C.R.-C.L. Rev. 275 (1997). (Themes 1, 2, 3, 5, 11).

Addresses the following question: Why are conservatives attempting not merely to roll back affirmative action but to destroy it root and branch? Notes that the controversy offers great benefits to the political right, yet bills, position papers, and referenda are aimed at eliminating affirmative action entirely. Speculates that this ground swell, coming on top of other conservative measures including immigration restriction and welfare cuts, is aimed at provoking the community of color into a militant reaction, which will be put down by force and followed by repressive legislation. Discusses possible roles the United States may have in store for Latinos in the new regime.

Delgado, Richard, Rodrigo's Twelfth Chronicle: The Problem of the Shanty, 85 Geo. L.J. 667 (1997). (Themes 1, 2, 3, 4, 5, 11).

Responds to Jane Larson's 'Free Markets Deep in the Heart of Texas."13 Argues that Larson's approach to the problem of the colonias, dirt-poor Mexican-American border towns situated on the outskirts of Texas cities like El Paso, is too narrow and risks perpetuating a woeful situation. Argues, based on social psychology and the dynamics of racial prejudice, that only aggressive aid in the form of governmental programs, environmental regulation, and individual activism will be able to remedy the problems of these shantytown settlements.

Delgado, Richard, Words that Wound: A Tort Action for Racial Insults, Epithets, and Name-Calling, 17 Harv. C.R.-C.L. L. Rev. 133 (1982). (Themes 1, 4).

Shows that tort law has stretched, not always successfully, to redress the harm of racial insults and name-calling. Employs social science to demonstrate how racism and racist insults harm their victims, and how law performs a vital role in curbing them. Argues that racist speech constructs a society at odds with our deepest commitments, and urges that courts recognize an independent cause of action to protect those values from bigoted speech.

13. Jane E. Larson, Free Markets Deep in the Heart of Texas, 84 GEO. L.J. 179 (1995). 
Delgado, Richard \& Vicky Palacios, Mexican Americans as a Legally Cognizable Class Under Rule 23 and the Equal Protection Clause, 50 Notre Dame L. Rev. 393 (1975). (Themes 3, 5, 8).

Surveys cases dealing with Mexican-American plaintiffs who sought to invoke constitutional protection, or to file a federal class action, as a cognizable group. Shows that many courts have difficulty deciding whether, for legal purposes, Mexican Americans or Chicanos exist. Some have Spanish surnames; some trace their ancestors to Mexico; some speak Spanish-and some do not. No trait is "essential" to being Latino. Argues that the group should be entitled to legal recognition because it enbraces a common culture, and because its members self-identify and are frequently subject to discrimination.

Delgado, Richard \& Jean Stefancic, Images of the Outsider in American Law and Culture: Can Free Expression Remedy Systenic Social Ills?, 77 Cornell L. Rev. 1258 (1992). (Themes 1, 4, 16).

Reviews 200 years of ethnic depiction in literature, theater, and film of Latinos/as and other peoples of color, demonstrating that in each era the dominant images were demeaning, although not seen as such at the time. Coins term "empathic fallacy" to denote the mistaken belief that one can readily talk back against the prevailing cultural images; shows that the marketplace of free speech intensifies rather than relieves the predicament of outgroups. Offers suggestions for outsider movements. Includes bibliography of writings on ethnic imagery.

Dunn, Timothy J., The Militarization of the U.S.-Mexico Border, 19781992: Low-Intensity Conflict Doctrine Comes Home (1996). (Themes $4,11,13)$.

Describes how "border control" through military strength came to occupy national consciousness. Shows how rhetoric escalated during the Reagan years, causing human rights and international sensitivity to recede in favor of firepower, helicopters, electronic sensors, and other high-tech hardware, all fueled by an illusory fear of drugs and massive illegal immigration. Shows how the federal government's border philosophy borrowed from low-intensity conflict doctrine, constructed by the U.S. military-security establishinent to deal with insurgent revolutionary regimes throughout the world. 
Espinoza, Leslie G., The LSAT: Narratives and Bias, 1 Am. U. J. Gender \& L. 121 (1993). (Theme 12).

Examines LSAT questions, revealing bias of several sorts. Some questions assume knowledge likely to be possessed only by majority-race test-takers or are based on associations that hold true only in majority culture. Other items incorporate stories that test-takers of color would find offensive, such as ones based on cultural stereotypes or criminality, and that might inhibit performance. Exposes the test agencies' history of resistance to reform and argues for continuing struggle to challenge them to delete questionable items from the test.

Espinoza, Leslie G., Masks and Other Disguises: Exposing Legal Academia, 103 Harv. L. Rev. 1878 (1990). (Themes 1, 2, 12).

Points out shortcomings of Randall Kennedy's critique of critical race theory, employing the metaphors of masking and demasking. Shows how neutralist and universalist strains in Kennedy's and classical liberalism's approach to racial justice limit their explanatory and liberatory potential. Cites personal experiences to illustrate these shortcomings and outlines a new, more community-based and contextual methodology.

Espinoza, Leslie G., Multi-Identity: Community and Culture, 2 Va. J. Soc. Pol'y \& L. 23 (1994). (Themes 2, 5, 6, 7, 12).

Discloses how "multi-identity" is not an accepted concept in the American lexicon of race and gender, and how the "politics of dichotomous categorical identity" either force individuals into categories or coerce them to choose a defining identity. Shows how this causes difficulties for women of color, such as Latinas, because it fragments their identities, forcing them to channel their experiences through either the discourse of race or that of gender and thus to deny their true multi-identities. Using classroom and courtroom examples, shows how everyday language contributes to these problems. Calls for a critical examination of legal language that will allow women and bilingual people to maintain all of their identities without penalty.

Freire, Paulo, Pedagogy of the Oppressed (1970). (Theme 12).

Starting with the premise that every human being has agencythat is, is a subject who can act upon and transform the worldBrazilian educator and philosopher Freire asserts that given critical 
tools, each person can become conscious of contradictions in personal and social reality and gain some control over his/her destiny. Offers pedagogical method for teaching reading to illiterate peoples to accomplish these goals. Contends that mastery changes consciousness by enabling people to overcome the fear of freedom, shed the identity of being only a responsive object, and instill the ability to question illegitimate authority.

García, Juan Ramon, Operation Wetback: The Mass Deportation of Mexican Undocumented Workers in 1954 (1980). (Themes 4, 11).

Studies the major factors that influenced the large influx of illegals during the Bracero Program during the 1940s and early 1950s, and the events that led to the mass roundup and deportation of undocumented Mexican workers in the United States in 1954. Examines the Bracero Program, conflicting policies of Mexican immigration, the border patrol, exploitation of illegals, and the rationale and attitudes used to justify this treatment, legislation proposed to penalize employers using illegal hands, and the planning of Operation Wetback. Demonstrates that the United States' unilateral efforts-mass deportations, restrictive measures, and contract labor programs-have not proved effective deterrents to illegal immigration.

Garcia, Ruben J., Critical Race Theory and Proposition 187: The Racial Politics of Immigration Law, 17 Chicano-Latino L. Rev. 118 (1995). (Themes 1, 5, 11, 14).

Applies critical history and labor-market analysis to show racist and-nativist background of Proposition 187, which denied welfare and other benefits to undocumented aliens in California. Argues that Mexican people are being used as scapegoats for U.S. workers pinched by consequences of poor economic policy at high levels. Argues that assimilationist measures like Proposition 187 are part of a broader attack on immigrants and other non-Anglo groups and that this movement uses a divide-and-conquer strategy by appealing to blacks and poor whites. Recommends that courts should give this and similar movements strict scrutiny. 
Gaspar de Alba, Alicia, The Alter-Native Grain: Theorizing Chicano/a Popular Culture, in Culture and Difference: Critical Perspectives on the Bicultural Experience in the United States 103 (Antonia Darder ed., 1995). (Themes $1,6,8,15,16$ ).

Examines theories of resistance in Chicano/a popular culture by analyzing cinematic portrayals of Chicanos/as. Explores the "cultural schizophrenia" that splits subject and object in Chicano identity as portrayed in the film Born in East L.A. Contrasts that approach to the romanticized, Anglo-produced The Milagro Beanfield War. Analyzes use of rasquachismo, a Mexican workingclass aesthetic of resistance to elitist standards in the art world, in Guillermo Gómez-Peña's performance video, Border Brujo. Points out the stereotypical treatment Chicanos/as have encountered and how modern Chicano filmmakers have countered these stereotypes.

Golden, Renny \& Michael McConnell, Sanctuary: The New Underground Railroad (1986). (Themes 2, 11, 13).

Explains the horror from which Central American refugees fled and sets out the moral and economic case for the U.S. sanctuary movement. Analogizes sanctuary workers to 19th-century abolitionists who helped slaves escape to freedom. Discusses deficiencies of official U.S. policy toward refugees, including prosecution of asylum workers. Contains case studies of Central Americans who fled oppression and violence in their home countries in hopes of securing freedom in the United States.

Gómez-Peña, Guillermo, Warrior for Gringostroika: Essays, Performance Texts, and Poetry (1993). (Themes 2, 6, 7, 8, 10, 15, 16).

Informed by his experience of biculturalism, Gómez-Peña-born in Mexico City and since 1978 a resident of the United States-challenges the opacity of the border between the two countries. Gómez-Peña, the "warrior for gringostroika," takes on kaleidoscopic identities with multiple voices-Mexican, postMexican, Chicano, Chicano/Mexican, Latin American, transAmerican, American-each speaking from a different perspective and uncovering ways Latino and Anglo culture have penetrated each other. Posits that border culture can lead to peaceful coexistence and cooperation and dismantle fear of the "other" that causes Mexicans, Chicanos, and Americans to view identity and culture as closed systems. Invites an imaginative leap into the psyche of the migrant, nomad, and exile to facilitate living in a world that is 
becoming increasingly hybrid and multidimensional. Contains performance texts Califas, Border Brujo, and 1992, as well as essays and poetry.

Gómez-Quiñones, Juan, Chicano Politics: Reality and Promise, 19401990 (1990). (Themes 1, 3, 4, 5, 6, 8, 10).

Describes the political experience of the Mexican people north of the Rio Bravo over a fifty year period. Shows how group consciousness took different forms at different times, including the liberal Chicano movement, conservativism, and empowerment. Shows the role of leadership, organization, ideology, and goals in representing Mexican-American people in the political arena. Describes how the struggle for political expression has had to confront condescension and demeaning stereotypes held by Anglo society. Argues that the political history of Chicanos in the United States cannot be understood without reference to issues of class and economic relations. Posits that Mexican unity and resistance are essential to long-lasting political advances.

González, Deena J., Chicana Identity Matters, in Culture and Difference: Critical Perspectives on the Bicultural Experience in the United States 41 (Antonia Darder ed., 1995). (Themes 6, 7, 8).

Examines the difficulty of defining and locating the identity of Chicanas. Explores the complexity of Chicana identity formation in the Southwestern United States during the nineteenth century. Discusses Chicana lesbian writers Gloria Anzaldúa, Alicia Gaspar de Alba, Cherrie Moraga, and Emma Pérez, and shows how their varied backgrounds led to different articulations of Chicana identity. Highlights the important implications for social struggle and change of the way culture assigns identities to its members - and the way those members accept or reject that assignment.

Gossett, Thomas F., Race: The History of an Idea in America (1963). (Themes 4, 5, 11, 16).

Explores how mandates of early English and Spanish explorers to convert the heathen to Catholicism shaped their theories of white racial superiority. Shows how pseudo-scientific definitions of race, based on early anthropology, social Darwinism, and the theory of Teutonic origins of freedom and democracy, were advanced by leading nineteenth-century intellectuals such as George Bancroft, Francis Parkman, and Henry Adams. Describes how the Social Gospel message proclaimed by Josiah Strong and others, which 
deemed Anglo Saxons to be God's chosen people, helped justify U.S. expansionism during the Texas and Mexican Wars, as well as in campaigns against the Indians. Argues that this racist legacy persists to this day.

Gotanda, Neil, A Critique of "Our Constitution is Color-Blind," 44 Stan. L. Rev. 1 (1991). (Themes 1, 5).

Argues that color-blind mythology in classic liberal thought promotes a system of white supremacy. Demonstrates that before deciding not to take account of race, one must first recognize it. Analyzes Supreme Court opinions to show the fallacy of the colorblind norm and how in each of its versions it suppresses the ability of courts to recognize and confront racist treatment and makes remediation difficult.

Grillo, Trina, Anti-Essentialism and Intersectionality: Tools to Dismantle the Master's House, 10 Berkeley Women's L.J. 16 (1995). (Themes 2, $5,6,12)$.

Explains how the concepts of intersectionality and antiessentialism may be used to challenge legal paradigms that tolerate racism and other oppressions. Applies intersectionality theory to show how the identity of women of color is fragmented in traditional legal analysis. Demonstrates how essentialism enshrines the white middle-class experience as the norm and excludes the multiple perspectives of other groups. Discusses experiences of multiraciality and current debates about adopting a multiracial category. Advocates increased efforts to understand ways race, gender, class, and sexual orientation relate to one another and to the operation of hidden privilege.

Gutiérrez, David G., Walls and Mirrors: Mexican Americans, Mexican Immigrants, and the Politics of Ethnicity (1995). (Themes 4, 6, 8, 10, $11,16)$.

Analyzes consequences of U.S. immigration policy for Mexican Americans residing in the United States, particularly in the border regions of California and Texas. Shows that anti-immigrant sentiment crosses class and race lines and that some Mexican Americans espouse restrictionist attitudes despite the emergence of a strong, nationalist Chicano movement. Suggests that immigration issues pose a threat to Mexican-American political and social integration, but that generally affinity ties are more important than differences. 
Gutiérrez, Ramón A., When Jesus Came, the Corn Mothers Went Away: Marriage, Sexuality, and Power in New Mexico, 1500-1846 (1991). (Themes 4, 6, 7).

Provides a social history of the Kingdom of New Mexico from 1500 to 1846. Describes the Spanish conquest of America and its impact on the Pueblo Indians. Explores how the institution of marriage determines the meanings of class, gender, and sexuality. Beginning with the premise that every society is hierarchical, uncovers how marriage has historically structured relations of inequality. Examines marriage customs among sixteenth and seventeenth century Pueblo Indians, particularly following the Spanish conquest and the influence of Franciscan clerical culture, and marriage formation and social control in eighteenth century New Mexico, including the Spanish recolonization after the Pueblo Revolt of 1680 . Focuses on how marriage in Spanish society was strictly administered to perpetuate inequalities. Seeks to provide understanding of cultural conflicts that occurred in nineteenth-century New Mexico, and which continue today between Anglos and Latinos.

Gutiérrez-Jones, Carl, Rethinking the Borderlands Between Chicano Culture and Legal Discourse (1995). (Themes 1, 2, 3, 4, 5, 6).

Examines ways traditional legal rhetoric has shaped the definition of Chicano history and created a social and legal culture of dependency. Shows how Anglo historical romances intended to provoke political and social reform such as Helen Hunt Jackson's Ramona ${ }^{14}$ and Edna Ferber's novel and George Stevens' film Giant ${ }^{15}$ fail because they do not take account of institutional blocks to equality. Discusses work by Chicana/o writers including Oscar "Zeta" Acosta, Ana Castillo, Cherríe Moraga, Alejandro Morales, Luis Valdez, and Helena Maria Viramontes, which depict trials and legal culture, often without the defects noted in the works of some Anglo writers. Explores Chicano/a writers' and critics' ambivalent attitudes toward law's objectivity and judicial neutrality. Examines how the rethinking and rewriting (i.e., cultural translation) of history and narratives might aid transformational efforts to reconstruct the legal system's treatment of Latinos.

14. HELEN HUNT JACKSON, RAMONA (1884).

15. EdNA FERBER, Giant (1952); GIANT (Warner Brothers 1956). 
Haney López, Ian F., Community Ties, Race, and Faculty Hiring: The Case for Professors Who Don't Think White, 1 Reconstruction No. 3, 1991, at 46. (Themes 1, 8, 12).

Argues for a race-conscious program of faculty hiring that takes into account not only the race and ethnicity of hires, but their community orientation as well. Points out that professors of color may serve as mentors and role models and enhance ties to the minority community. Defends race-conscious hiring from objections that it is essentialist, ill-defined, unfair to innocent whites, and saddles professors of color with unfair expectations and burdens.

Haney López, Ian F., The Social Construction of Race: Some Observations on Illusion, Fabrication, and Choice, 29 Harv. C.R.-C.L. L. Rev. 1 (1994). (Themes 1, 3, 5, 8).

Argues that race is a social, not a biological construction; that is, terms like black, white, Latino, and Asian denote social, not genetically distinct groups. Shows how law has been used to reinforce racial subordination. Reveals how racial divisions are relatively new constructions, subject to constant change.

Haney López, Ian F., White by Law: The Legal Construction of Race (1996). (Themes 1, 3, 4, 5).

Explores the social and legal origins of white racial identity by examining naturalization cases instrumental to the formation of modern images of race, law, and whiteness. Theorizes that law operates to construct races. Focuses on the role of law in creating and legitimating social ideas regarding race, and also on the legal structuring and maintenance of the material inequalities that give race an abiding salience in our society. Shows how "whiteness" is subconsciously thought of as the norm and how most whites think of their race as transparent. Argues that whites need to acknowledge and give up their white privilege before racial equality can be obtained.

Harris, Angela P., Race and Essentialism in Feminist Legal Theory, 42 Stan. L. Rev. 581 (1990). (Themes 1, 2, 5, 6).

Analyzes essentialism-the assumption of a single, united notion of woman-in contemporary feminist thought. Shows that this assumption discounts the perspectives and needs of women of color and disempowers them. Shows how essentialism operates in the writing of leading theorists of feminism. Suggests incorporation of 
multiple consciousness and attention to storytellers of color as antidotes for essentialism.

Harrison, Melissa \& Margaret E. Montoya, Voices/Voces in the Borderlands: A Colloquy on Re/Constructing Identities in Re/Constructed Legal Spaces, 6 Colum. J. Gender \& L. 387 (1996). (Themes 2, 4, 5, 12).

Shows how the Spiegel catalog and Ralph Lauren ads both extol and neutralize cultural diversity by juxtaposing words such as exotic, primitive, and ethnic with plantation images associated with colonialism, racism, and imperialism. Argues that legal discourse resembles this commercial-speak in masking historic forms of subordination. Contends that marketplace consumption can imply racist complicity, just as legal discourse can encourage monocular perspectives. Uses concept of the borderlands as a way to challenge essentialist thinking and enable lawyers to understand the role of difference in their clients'. perspectives. Discusses ethnography and translation studies, and.warns of the Malinche paradox wherein even the best efforts of outsider lawyers to translate their clients' stories sometimes unexpectedly fail. Includes client Frank Baca's story to illustrate the problem of translation and the complexity of representing and speaking for a disabled client.

Hernández-Truyol, Berta Esperanza, Building Bridges-Latinas and Latinos at the Crossroads: Realities, Rhetoric and Replacement, 25 Colum. Hum. Rts. L. Rev. 369 (1994). (Themes 2, 3, 5, 6, 8, 14, 16).

Critiques the "exclusionary normative-centric model" of legal analysis, which uses a single-trait approach, wherein diverse traits become monocular characterizations-race equals black, gender means female, ethnic implies Latina/o, and so on. Argues that this approach leads to a black/white dichotomy that marginalizes Latinas/os wherein both whites and blacks perceive Latinas/os as "other." Posits that the multiple perspectives of Latinas/os, who stand at the crossroads of race, ethnicity, and gender, are critical to the development of universality-an acceptance of the complexities of all persons and an understanding of the "multidimensionality" that is our deepest commonality. Concludes that the Latina/o invisibility that the prevalent black/white model creates puts the group in the unique position of being outside both the white majority and the black minority, enabling them to build bridges and create a new visibility embracing multiple perspectives. 
Hernández-Truyol, Berta Esperanza, Natives, Newcomers and Nativism: A Human Rights Model for the Twenty-First Century, 23 Fordham Urb. L.J. 1075 (1996). (Themes 3, 5, 11, 13).

Discusses the history of nativism and mistreatment of immigrants, including Italian, Irish, Jewish, German, Japanese, and Latino groups. Explores continuing nativist sentiment, evidenced in California's Proposition 187 and the official-English movement, against darker skinned and non-Western immigrants. Describes alienage discrimination, reviewing various rights limitations placed on non-citizens in areas such as welfare reform, voting, and employment. Examines Supreme Court decisions on U.S. sovereignty that exclude aliens, but notes that human rights conventions provide some limit to that power. Urges adoption of international human rights norms to counteract the unfettered sovereignty concept and to extend more rights to aliens.

Hernández-Truyol, Berta Esperanza, Sex, Culture, and Rights: A $\mathrm{Re} /$ conceptualization of Violence for the Twenty-First Century, $60 \mathrm{Alb}$. L. Rev. 607 (1997). (Themes 1, 5, 7, 13).

Examines attempts to gain equality for women, including Latinas, around the world. Notes that subordination of women is not ceasing. Observes that exclusion of women in the crafting of early human rights documents contributed to their lack of protection from gender-based abuses. Advocates redefining violence using a gender-sensitive perspective to include not only physical but psychological, political, and cultural acts that subjugate women. Suggests that such a reformulation would condemn all abusive conduct, including economic marginalization, which perpetuates women's subordinated status.

Herrera-Sobek, María, The Bracero Experience: Elitelore Versus Folklore (1979). (Themes 2, 4, 6, 8, 15, 16).

Analyzes the bracero experiences of the 1940 s and 1950 s by looking at elitelore (the writings of Mexican intellectuals) and folklore (interviews with various generations of bracero workers and folk songs about migrant farm life). Concludes that elite Mexican writers were generally highly critical of bracero workers, deeming them exploited in the United States and a drain of the best labor in Mexico, and thereby reinforcing an inferior image of the Chicano. Contrasts interviews with various bracero workers who, though faced with racism in the United States, reported generally positive experiences, 
using money and knowledge gained in the United States to improve their lives and those of their children in Mexico.

Herrera-Sobek, María, The Mexican Corrido: A Feminist Analysis (1990). (Themes 2, 6, 7, 16).

Explores the portrayal of women in over 3,000 corridos (Mexican folk ballads). Argues that the creation and crystallization of an archetype in a society is the result of historical process and not merely a preconscious mental construct. Identifies four components that forcefully structure archetypal images found in the Mexican folk ballad: patriarchal ideology, social class of the corridista and the corrido audience, Mexican history and Western literary tradition, as well as four recurrent images: the good and bad mother, the mother goddess, the lover, and the soldier. Advocates using these archetypes to analyze representation of women in corridos.

Horsman, Reginald, Race and Manifest Destiny: The Origins of American Racial Anglo-Saxonism (1981). (Themes 1, 4, 5, 11, 16).

Examines how the phrase "manifest destiny" was coined to legitimate U.S. military aggression and advance America's self-dealt special role in world history. Shows how this notion has led to the belief that the role of conquered "inferior" people is to retreat or disappear. Argues that the idea of Anglo-Saxonism as constituting a separate, innately superior people crystallized when whites needed to explain U.S. expansionist interests that culminated in the Mexican War of 1846-1848. Shows how journalists, novelists, travel writers, and politicians promoted this idea to label Mexicans an inferior mongrel race. Asserts that early American anathema toward granting citizenship to conquered Mexicans residing within U.S. borders enshrined enduring stereotypes of them into U.S. racial mythology.

Iglesias, Elizabeth M., Rape, Race and Representation: The Power of Discourse, Discourses of Power, and the Reconstruction of Heterosexuality, 49 Vand. L. Rev. 869 (1996). (Themes 3, 6, 7, 16).

A Latina feminist perspective on images of female sexuality as they affect the culture of heterosexuality and rape. Argues that legal strategies aimed at reforming criminal laws will not eliminate rape because case processing decisions are discretionary, aimed only at after-rape intervention, and linked to a culture in which male power depends upon female powerlessness and in which culturally dominant narratives of race and sexual identity render it dangerous 
to be a woman of color. Examines alternative images of women and men that could be used to reform legal doctrine and policy.

Iglesias, Elizabeth M., Structures of Subordination: Women of Color at the Intersection of Title VII and the NLRA. Not!, 28 Harv. C.R.-C.L. L. Rev. 395 (1993). (Themes 1, 5, 6, 7).

Argues, in opposition to the legal storytelling movement, that many of the mechanisms of oppression for women of color in the workplace stem from poor laws and lack of collective organization. Reasons that sensitivity training, agony tales, and a focus on meaning and anecdote have largely exhausted their potential and that it is time for progressive lawyers to begin the task of organizing workers and unmasking the operation of legal power.

Iguana Dreams: New Latino Fiction (Delia Poey \& Virgil Suarez eds., 1992). (Themes $2,6,9,11,15$ ).

Presents twenty-nine stories by Latino/a writers representing Chicano, Mexican, Puerto Rican, Cuban, Chilean, and Dominican cultures. Virtually all are united by the experience of bilingualism and the ability to blend two languages effectively and expressively. Recurrent themes include cultural survival and assimilation, nostalgia and reminiscence, intergenerational alienation, and attitudes toward women.

Immigrants Out! The New Nativism and the Anti-Immigrant Impulse in the United States (Juan F. Perea ed., 1997). (Themes 1, 4, 8, 11).

Essays examine changing relationships between citizens and immigrants in the United States from the Alien and Sedition Acts of 1798 to the recent Proposition 187 in California. Explores semantics, rhetoric, and the impact of economics, history, and demographics on the way nativism continues to influence national policy.

Infinite Divisions: An Anthology of Chicana Literature (Tey Diana Rebolledo \& Eliana S. Rivero eds., 1993). (Themes 2, 6).

Presents 178 oral and written narratives representing 56 authors. Contains texts exploring personal identity, familial relationships, public and private spaces, myths and archetypes, and.empowering events. Introduction gives overview of history of Chicana storytellers and writers from colonial and Anglo conquest periods through Chicana Renaissance of 1970s and 1980s. 
Johnson, Kevin R., Civil Rights and Immigration: Challenges for the Latino Community in the Twenty-First Century, 8 La Raza L.J. 42 (1995). (Themes 1, 3, 8, 11, 14).

Argues that immigration and rapidly changing Latino demographics in the United States make political, as opposed to purely legal, strategies essential to improving the situation of Latino peoples. Points out that the need to emphasize political action results largely from deficiencies of traditional civil rights solutions pioneered by the African-American community, which, because of the complex heterogeneity of the Latino community, work less well for it. Asserts that increased political mobilization of Latinos, coupled with voting-reform litigation, is the most prudent long-term strategy for transcending limitations of the black/white civil rights model, and for eventually developing a civil rights coalition that bridges minority boundaries.

Johnson, Kevin R., An Essay on Immigration Politics, Popular Democracy, and California's Proposition 187: The Political Relevance and Legal Irrelevance of Race, 70 Wash. L. Rev. 629 (1995). (Themes $1,3,11,14)$.

Shows how California's Proposition 187, which limited governmental services to undocumented workers and required governmental employees to report suspected undocumented immigrants, was facially neutral with respect to race; like similar past legislation, however, it was aimed at Mexican Americans. Examines difficulty of challenging subordination of minority interests because of requirement to prove conscious intent to discriminate. Notes reluctance of some African Americans to oppose restrictive immigration measures because of feared economic competition by growing numbers of Latino and Asian immigrants.

Johnson, Kevin R., Fear of an "Alien Nation": Race, Immigration, and Immigrants, 7 Stan. L. \& Pol'y Rev. 111 (1996). (Themes 9, 11, 14).

Critiques Peter Brimelow's Alien Nation: Common Sense About America's Immigration Disaster. ${ }^{16}$ Argues that Brimelow has made scapegoats of Latino/a immigrants, blaming them for the nation's political, economic, and social problems, namely affirmative action, bilingual education, and environmental degradation. Identifies a contradiction in Brimelow's nativist position, in that he opposes

16. Peter Brimelow, Alien Nation: Common Sense about America's immigration DISASTER (1995). 
Latino immigration because he feels Latinos/as do not want to assimilate, but nevertheless opposes funding for programs that encourage assimilation, such as English as a Second Language. Explores how immigration is used as a wedge between the black and Latino communities, by blaming immigrants for taking away unskilled jobs from black workers.

Johnson, Kevin R., Free Trade and Closed Borders: NAFTA and Mexican Immigration to the United States, 27 U.C. Davis L. Rev. 937 (1994). (Themes 11, 13, 16).

Examines the relationship between illegal immigration from Mexico and the North American Free Trade Agreement (NAFTA). Explains that some economic agreements, such as the one among members of the European Union, have abolished many migration restrictions between member nations. Contends that immigration was not addressed during the ratification of NAFTA because immigration from Mexico is highly unpopular in the United States with, on the left, trade unions and environmental organizations who fear the loss of "American" jobs and degradation of the environment, and, on the right, restrictionists who fear that the United States will be corrupted by an influx of inferior people of color. Shows how easily rights of minority peoples become submerged when political interests take precedence.

Johnson, Kevin R., Los Olvidados: Images of the Immigrant, Political Power of Noncitizens, and Immigration Law and Enforcement, 1993 BYU L. Rev. 1139. (Themes 2, 5, 11, 16).

Explains how the electoral powerlessness of noncitizen immigrants, combined with economic hard times, anti-immigrant sentiment, and the lack of political mobilization around immigration issues, results in a dysfunctional political system. In this system, a well-organized vocal minority of citizens dedicated to restrictionist immigration policies actively represents the "silent majority" of voters on immigration issues. Because the political system does not accurately gauge the will of the public, immigration reformers must change the negative collective images of the immigrant in the national consciousness by telling the untold stories about the lives of noncitizens in the United States. 
[Vol. 85:1509

Johnson, Kevin R., "Melting Pot" or "Ring of Fire"? Assimilation and the Mexican-American Experience, 85 Calif. L. Rev. 1259 (1997), 10 La Raza L.J. 173 (1997). (Themes 2, 8, 15).

Argues that assimilation poses special dangers for Latino people, even those of high educational and professional attainment. Reflecting on his own experience as a person of mixed race, shows that race is indeed a social construct and, for many, a matter of personal choice and identification. Nevertheless, notes that full acceptance by mainstream society can rarely be achieved by darkerskinned persons of color, while the effort to pass oneself as white or European exacts great costs. Argues that mixed-race persons are best advised to accept their own racialized status and resist the temptation to "pass." Urges that individuals and society alike acknowledge the line-drawing problems posed by racial mixture.

Johnson, Kevin R., Public Benefits and Immigration: The Intersection of Immigration Status, Ethnicity, Gender, and Class, 42 UCLA L. Rev. 1509 (1995). (Themes 6, 10, 11, 14, 16).

Shows the "quadruple whammy" faced by undocumented domestic workers - discrimination on the basis of class, gender, ethnicity, and citizenship. Examines how current anti-immigrant sentiments continue a long tradition of nativist fervor. Reveals how poor African Americans and Asians fear illegal Latino immigration as competition that reduces wages and the number of available jobs. Criticizes how anti-immigrant legislation, such as California's Proposition 187, has been used to target Mexicans as inferior and undesirable people-stereotyping Mexican women as welfare queens and Mexican men as criminals, despite data that show only a small percentage of undocumented workers receive welfare or commit crimes. Argues that most of the anti-immigrant legislation and enforcement has been directed against Mexicans and other Latin Americans, even though just as many undocumented workers from other countries have overstayed their tourist, student, or business visas. Urges coalition by subjugated groups as a way of increasing their political power. 
Johnson, Kevin R., Racial Restrictions on Naturalization: The Recurring Intersection of Race and Gender in Immigration and Citizenship Law, 11 Berkeley Women's L.J. 142 (1996). (Themes 3, 4, 5, 6, 8, 11, 14).

Reviews Ian Haney López's White By Law, ${ }^{17}$ paying particular attention to issues the author leaves open, including the questions of why whites should disassemble their own whiteness and how communities of color should deal with degrees of "whiteness" in their own midst (viz., the way some Latinos or blacks look lighter than others). Praises Haney López for drawing attention to the way gender operates in immigration and naturalization law, and shows additional ways in which scholars can explore this area. Argues that another function of law may be to "allow for more sophisticated discrimination," as in Latin American countries populated by people of color but where discrimination against darker or more indigenous-looking people is nevertheless rife. Argues that the transformation of the country's demographics and the United States' increasing multiracial makeup may generate tensions that ultimately yield beneficial change.

Johnson, Kevin R., Some Thoughts on the Future of Latino/a Legal Scholarship, 2 Harv. Latino L. Rev. (forthcoming 1997). (Themes 1, 3, $8,14)$.

Describes how critical Latino/a theory, separate but similar in approach to critical race theory, needs to reconstruct civil rights discourse to accommodate Latino/a perspectives because the black/white paradigm fails to speak to important issues for the Latino community. Suggests that changing U.S. demographics imply an emerging multicultural society, with race relations a multilateral, rather than bilateral, phenomenon. Points out that, because diversity among Latinos/as makes it difficult to identify commonalities within the community, developing a LatCrit theory is a formidable task. Urges that areas for analysis would include: immigration reform; bilingual educational opportunities; maintaining Latino cultural identity in the face of cultural assimilation; challenging the stereotype of the Latino/a as foreigner; and examining racism, misogyny, and homophobia in the Latino community.

17. Ian F. Haney López, White by Law: The Legal Construction of Race (1996). 
Johnson, Kevin R., Why Alienage Jurisdiction? Historical Foundations and Modern Justifications for Federal Jurisdiction Over Disputes Involving Noncitizens, 21 Yale J. Int'l L. 1 (1996). (Themes 3, 5, 11).

Urges that reform or cutbacks of federal diversity-of-citizenship jurisdiction avoid reducing the category of federal subject-matter jurisdiction based on alienage. The two categories, although superficially similar, rest on different policy grounds; in particular, alienage jurisdiction serves as an essential protection against xenophobia in local courts. Moreover, in a period of increasing globalization it is in the United States' interest to maintain a federal forum for suits in which a party is a noncitizen. Urges congressional action to assure that alienage jurisdiction survives in the future.

Larson, Jane E., Free Markets Deep in the Heart of Texas, 84 Geo. L.J. 179 (1995). (Themes 3, 4, 6, 11).

Examines the condition of Mexican Americans living in the colonias-shantytowns lining the Texas-Mexico border. Reports fieldwork and interviews revealing substandard conditions prevailing in these settlements, including lack of running water and sewers, unsafe housing, and no street lighting or addresses. Notes the dilemma posed by both liberal thought and classical economics: regulation could price the colonistas out of the only place they can afford to live. Acknowledges the contribution of racist attitudes among white Texans in tolerating these slums, and proposes a seven-part solution including self-help housing, minimal regulations, and extending the franchise in local elections to noncitizens.

The Latino Encyclopedia (Richard Chabrán \& Rafael Chabrán eds., 1996). (Themes 1, 4, 7, 8, 9, 10,11, 12, 15, 16).

The first encyclopedia of its kind, co-edited by the brothers Chabrán-Richard, director of UCLA's Chicano Studies Research Library and Rafael, a professor of Spanish-comprises a six volume collection of almost two thousand essays by academics and researchers on Latino history and culture in the United States. Subjects covered include politics, education, literature, art, folklore, religion, sports, science, and medicine. Includes Puerto Rican Americans and Cuban Americans, as well as Mexican Americans. 
Latinos and the Political System (F. Chris García ed., 1988). (Themes 1, $3,4,5,8,14)$.

Discusses Latino successes in the U.S. political system, examining the three major Latino groups-Mexican Americans, Cuban Americans, and Puerto Ricans. Emphasizes the political movement during the 1980s, categorized as the "Decade of the Hispanic." Includes essays by well-known Latinos/as, organized in accord with David Easton's model of political systems: inputs, conversions, outputs, and feedback. Describes tensions among the different groups and argues that tactics successful in the 1970s failed in the 1980 s because of the reluctance of non-Hispanics to support causes they did not see as immediately beneficial to themselves.

Latinos in the United States: History, Law and Perspective (Antoinette Sedillo López ed., 1995). (Themes 1, 3, 4, 5, 6, 7, 8, 9, 11, 12, 16).

Six volume set on Latino/a legal history and scholarship reprinting 110 articles from law reviews, anthologies, and journals in anthropology, Chicano studies, education, history, political science, Puerto Rican studies, social policy, sociology, and women's studies. The volumes cover:

1. Historical Themes and Identity: Mestizaje and Labels. Focuses on history of Latino peoples in California, the southwest and midwest, Florida, Cuba, and Puerto Rico, with particular emphasis on legal history and doctrine, the role of women, racism, stereotyping, conflicts with Anglos, and ethnicity and identity.

2. Latina Issues: Fragments of Historia(Ella) (Herstory). Addresses Latina perspectives on colonization; gender, race, class, and their intersections; cultural values; work histories; family roles; reproductive issues; and the failure of the women's and Chicano movements to include Chicana perspectives.

3. Criminal Justice and Latino Communities. Reviews and critiques the legal system's treatment of Latinos, showing how deficiencies in criminological research techniques, disparate sentencing, cultural bias, and language barriers contribute to Latinos' lack of confidence in the criminal justice system.

4. Latino Employment, Labor Organizations and Immigration. Examines Latino labor history from 1850 to the present, including critique of U.S. immigration law showing how immigration policy protects U.S. labor needs but neglects human rights of immigrants.

5. Latino Language and Education. Contains essays by linguists, historians, educators, and law professors on language rights, English-only 
rules, bilingual education, school segregation and ability grouping, and affirmative action.

6. Land Grants, Housing and Political Power. Examines nineteenthcentury land grant processes and policies, housing conditions and fair housing policies, and Latino access to and use of the political process.

Lionnet, Françoise, Autobiographical Voices: Race, Gender, SelfPortraiture (1989). (Themes 2, 4, 6, 7, 15).

Analyzes and compares the autobiographical texts of Augustine and Nietzsche with those of five twentieth-century women writersHurston, Angelou, Cardinal, Conde, and Humbert-from cultures with a high degree of hybridity. Juxtaposes these seemingly disparate texts with Augustine and Nietzsche, not so much to highlight the contrast with modern feminine visions, but rather to unearth the subjugated feminine voice within the masculine autobiographical tradition. Advocates concurrent readings of dissimilar texts for novel insights about historically constraining conceptual categories and to unmask mechanisms that perpetuate the sociocultural construction of race and gender as inferior. Argues for metissage, the braiding of indigenous cultural forms with Western concepts, as a means of enabling women to find the strength to persevere despite a culture that is arrayed against them.

López, Gerald P., The Idea of a Constitution in the Chicano Tradition, 37 J. Legal Educ. 162 (1987). (Themes 1, 2, 5, 10).

Considers the notion of a constitution from the perspective of the Chicano community. Points out that, far from being a noble document, a constitution may easily cause injury by empowering some and not empowering others. Discusses the role of struggle in shaping and giving life to a constitution.

López, Gerald P., Lay Lawyering, 32 UCLA L. Rev. 1 (1984). (Themes $2,5,12$ ).

Shows the role of scripts and stock stories in the way people organize experiences, including those of justice and injustice. Describes how society attaches certain stock meanings and interpretations to recurring experiences, including ones of legality and illegality. Illustrates all these operations by means of an account of a mother and son trying to hail a taxicab in a busy city. 
López, Gerald P., Rebellious Lawyering: One Chicano's Vision of Progressive Law Practice (1992). (Themes 1, 2, 5, 12).

Analyzes practices of progressive lawyers in representing poor clients. Shows that many of these lawyers follow unconscious practices that inhibit reform and impede their ability to advance their clients' interests. Argues for a form of rebellious lawyering characterized by radical identification with the client community and an unending struggle to understand, incorporate, and give voice to that community.

López, Gerald P., Reconceiving Civil Rights Practice: Seven Weeks in the Life of a Rebellious Collaboration, 77 Geo. L.J. 1603 (1989). (Themes $1,2,3,5,12)$.

Focuses on the underlying ideas of rebellious lawyering in relation to $\$ 1983$ litigation. Presents a fictional account of a relatively inexperienced young lawyer who learns to work not only for but with her client in a federal civil rights action. Demonstrates the importance of collaboration with allies and situating oneself in the community of the client.

López, Gerald P., Training Future Lawyers to Work with the Politically and Socially Subordinated: Anti-Generic Legal Education, 91 W. Va. L. Rev. 305 (1989). (Themes 1, 5, 12).

Discusses reluctance of law schools to provide training for lawyers who will work with subordinated groups. Addresses the indifference of a legal education that perpetuates generic legal skills training which harbors a blindness to differences in the social conditions and lives of clients. Presents ways to implement a new vision based on the redesigned Stanford Lawyering for Social Change curriculum.

López, Gerald P., Undocumented Mexican Migration: In Search of a Just Immigration Law and Policy, 28 UCLA L. Rev. 615 (1981). (Themes 1, 4, 11).

Criticizes historical U.S. immigration policy toward Latin America as cruel, unjust, and based on a misunderstanding of the forces that propel immigration. Argues that the current negative understanding of undocumented immigration is mistaken, and that national selfinterest would be better advanced by a more generous approach to Mexican immigration. 
López, Gerald P., The Work We Know So Little About, 42 Stan. L. Rev. 1 (1989). (Themes 1, 2, 12).

Describes struggle of an undocumented Mexican immigrant who attempts to support her family by low-pay housekeeping. Follows her journey to citizenship, her fear of deportation, her struggle to prove her residency with no paper trail, and her attempts to fulfill the education requirement. Highlights her distrust of the legal profession, and illustrates how pervasive this view is among low-income women of color. Urges that the legal profession's relation to working-class clients must change, and argues that this will in turn affect low-income women's perceptions of the law, allowing them to feel comfortable in seeking a lawyer for help.

Luna, Guadalupe T., "Agricultural Underdogs" and International Agreements: The Legal Context of Agricultural Workers Within the Rural Economy, 26 N.M. L. Rev. 9 (1996). (Themes 4, 11, 13).

Examines how the agriculture industry in the United States benefits from federal entitlements that offset the costs of accommodating labor demands but fail to provide any benefits for farm workersespecially those of Mexican descent. Asserts that exemptions from labor and immigration law have increased because of the liberalization of global agricultural markets by NAFTA, but without providing appreciable benefits or protections to agricultural workers. Points out that underrepresentation of Latinos as farm operators is a result of a historical power imbalance and that a parochial emphasis on labor law has guaranteed that Chicana/o farm workers lead a marginal existence. Proposes that conditions can be improved by using as models international agreements that shift the emphasis from macroeconomic entitlement policies to regionally determined criteria for distribution of agricultural benefits. Provides a case study of the colonias of the El Paso border region, where the Latino population is significant but Chicana/o farm ownership is minimal. Concludes that policies that enhance the diversity of farm ownership can better address issues of equality, farm preservation, and the quality of food and life in the United States.

Maciel, David R., El Norte: The U.S.-Mexican Border in Contemporary Cinema (1990). (Themes 7, 15, 16).

Examines the depiction of Chicanos/as in Mexican and U.S. films about life along the border. Reviews the most popular border films, finding that both Mexican and U.S. commercial films stereotype Chicanos/as as lazy, dirty, crude, stupid, or as criminals, or helpless 
and passive victims. Concludes that independent films made by Chicano writers and/or directors are generally devoid of stereotypes and forcefully depict important social issues that confront the lives of people who live along the border.

Making Face, Making Soul Haciendo Caras: Creative and Critical Perspectives by Women of Color (Gloria Anzaldúa ed., 1990). (Themes $2,6,7,12,15)$.

Continues the work originally presented in This Bridge Called My Back. ${ }^{18}$ Anthologizes eighty-three selections by women of color challenging identities traditionally assigned to them by others. By haciendo caras (making faces), the authors define themselves and construct their identities anew. Divided into seven parts, the selections address racism; sexism; internalized oppression; silencing and repressed voices; alliances with communities, other ethnic groups, and marginalized whites; critical theory; self-perception and identity. The introduction and various essays recount experiences and techniques used to confront racism in the classroom, in women's studies programs, and in the women's movement.

Martínez, Elizabeth, Beyond Black/White: The Racisms of Our Time, 20 Soc. Just. 22 (1993). (Themes 1, 4, 8, 11, 14).

Analyzes effects of defining racial issues in terms of a black/white framework that excludes the experiences of Latinos, Native Americans, and Asian Americans. Points out that worldwide economic recession, changes in the international labor market and consequent migration, and backlash against the 1960s civil rights agenda have increased racism against all peoples of color and increased tensions among racial and ethnic groups bent on survival. Compares histories of African Americans and Latinos and argues that Latinos are defined and oppressed by language, cultural, and nationality issues, as well as by race. Calls for a discussion of racism in a framework that includes the experiences of all groups of color.

Martinez, George A., The Legal Construction of Race: Mexican Americans and Whiteness, 2 Harv. Latino L. Rev. (forthcoming 1997). (Themes 1, 3, 5, 16).

Examines how the legal system has classified Mexican Americans in various settings, including jury service, immigration and naturalization, and for the purpose of filing class actions. Concludes that

18. This Bridge Called My BaCK (Cherríe Moraga \& Gloria Anzaldúa eds., 1981). 
judges generally find Mexicans white only when no benefit-and usually a burden-rides on it. When being white would bring a disability such as exclusion from jury service, courts have not hesitated to pronounce Mexican-American people white. Moreover, even when courts classify Mexican Americans as white, this classification brings few benefits outside court; the rest of society continues to regard Mexicans as inferior and "other."

Martinez, George A., Legal Indeterminacy, Judicial Discretion and the Mexican-American Litigation Experience: 1930-1980, 27 U.C. Davis L. Rev. 555 (1994). (Themes 1, 2, 3, 5).

Examines key court decisions in Mexican-American civil rights cases in the areas of public accommodations, land grants, restrictive covenants, racial slurs, school desegregation, and bilingual education. Shows how courts have generally decided against MexicanAmerican plaintiffs when not constrained by Supreme Court precedents. Argues that many decisions are not inevitable or logically compelled, but rather the result of discretionary or discriminatory policy choices. Describes how some civil rights strategies used successfully by African Americans failed when similar cases were brought by Mexican Americans. Concludes that litigators should deploy and courts should heed counterstories to overcome dominant perspectives when deciding politically sensitive cases or one's of first impression.

Martinez, John, Trivializing Diversity: The Problem of Overinclusion in Affirmative Action Programs, 12 Harv. BlackLetter L.J. 49 (1995). (Themes 5, 12).

Discusses overinclusion in affirmative action programs resulting from a lack of generally accepted standards by which to determine diversity status. Argues that the lack of such standards encourages institutions not to examine critically an applicant's self-designated minority status, in order to pad their diversity statistics. Cites examples such as a woman who checked the Hispanic box on her application, and, when questioned, replied that she was "Hispanic by birth" because her ex-husband had been Hispanic and she had a child by him. Proposes a reconstruction of affirmative action programs to seek two possible ends, "enrichment" and "social justice." Argues that we should abandon the use of suspect-trait proxies, such as race and gender, as means to achieve those ends, and that we should rely instead on an individualized inquiry into 
each candidate's history of employment, services, and contacts to determine inclusion in affirmative action programs.

McWilliams, Carey, North From Mexico: The Spanish-Speaking People of the United States (1949). (Themes 1, 4, 5, 10,11, 16).

Early critical history of Mexicans in the United States points out the irony of, on the one hand, Anglo culture's fascination with romanticized mythology of Spanish and Californian influence in the West, and on the other, its determined efforts to subordinate Mexican Americans. Discusses how the failure of Spanish settlements north of the Rio Grande to link borderland outposts impeded the ability of Mexican settlers to function together politically. Shows how, with the passage of the 1924 Immigration Act, social work agencies and Americanization institutes, fearing loss of clients, defined a new area-"the Mexican Problem"- to justify their continuance. Reveals how data they collected were interpreted to "prove" various demeaning stereotypes about Mexicans, such as lack of character, discipline, intelligence, and thrift. Links the removal of Japanese Americans in California to internment camps during World War II with the substitution in the media of Mexicans as a major scapegoat group, leading in turn to the Sleepy Lagoon event and consequent Zoot Suit riots. Projects hope for a good neighbor policy with Mexico after World War II (which did not materialize).

Menchaca, Martha, Chicano Indianism: A Historical Account of Racial Repression in the United States, 20 Am. Ethnologist 583 (1993). (Themes 1, 3, 5, 8, 11, 15).

Discusses racial repression of people of Mexican origin in the U.S. legal system from 1848 to 1947 . Shows how, after Mexico turned over one third of its land to the United States under the Treaty of Guadalupe Hidalgo in 1848, Mexican nationals (most of them mestizo) were placed in legal limbo. Because U.S. citizenship originally was granted to free whites only-and after the Fourteenth Amendment to blacks, but not Indians-people of Mexican descent were compelled to argue in court that they should be treated as Caucasians in order to gain citizenship. Uses nineteenth-century court records and citizenship legislation to show that Mexicans who appeared to be Indian or nonwhite were more severely discriminated against than ones who were classified as white or could prove their ancestry was predominantly white. 
Méndez, Miguel A., Hernandez: The Wrong Message at the Wrong Time, 4 Stan. L. \& Pol'y Rev. 193 (1993). (Theme 5, 9).

Analyzes Hernandez v. New York, ${ }^{19}$ the United States Supreme Court decision that upheld the right to eliminate a prospective bilingual juror if the prosecutor suspected that the juror would not abide by the official court translation of the testimony of a non-English speaking witness. Examines Batson v. Kentucky, ${ }^{20}$ which prohibited peremptory challenges that disqualify a juror on account of his race, concluding that Batson gave only symbolic opposition to racial discrimination because the burden of persuasion on defendants makes proving the prosecutor eliminated jurors because of their race difficult. Argues that because many Latinos/as are bilingual, Hernandez will make it easier for prosecutors to exclude Latinos/as from serving on juries. Ironically, thus, the current law excludes super-competent jurors in favor of others less able, forfeiting the goals of justice in favor of sterile proceduralism.

Miles, Jack, Black vs. Browns: African Americans and Latinos, Atlantic Monthly, Oct. 1992, at 41. (Themes 6, 8, 10, 11, 14).

Argues that the Los Angeles riots following the acquittal of four white police officers who assaulted Rodney King reflected not only black/white enmity but also increasing tensions among the black, Latino, and Asian communities. Traces this tension to immigration and competition for jobs and social programs. Theorizes that whites are more comfortable employing Latinos than African Americans, and with the large increase in the illegal Latino immigrant work force who will: work for lower wages, fewer jobs are available for African Americans. Examines debate among conservatives, some of whom want open borders with free trade of goods and labor, and others of whom oppose non-European immigration because they want to preserve whiteness in the United States.

Mirandé, Alfredo, "En la Tierra del Ciego, El Tuerto Es Rey" ("In the Land of the Blind, the One Eyed Person is King"): Bilingualism as a Disability, 26 N.M: L. Rev. 75 (1996). (Theme 1, 9).

Shows how English-only rules devalue and punish Spanish speakers. Argues for a reformulation of employment discrimination law and equal protection doctrine to address differences among protected groups. Asserts that for Latinos, language, though less visible

19. 500 U.S. 352 (1991).

20. 476 U.S. 79 (1986). 
than race, is an immutable characteristic that should be viewed as a workplace disability subject to the provision of reasonable accommodation by employers.

Mirandé, Alfredo, Gringo Justice (1987). (Theme 1, 4, 5, 16).

Traces the experience of Chicanos in the U.S. legal and judicial system from 1848 to the present, describing clashes between Anglos and Mexicans over land rights and labor disputes. Asserts that a donble standard of justice treats Anglo Americans differently from Chicanos. Argues that the U.S. takeover of Mexico resulted in the displacement and subjection of Chicano people who were forced to live in an alien legal and judicial system that subordinates Chicanos. Rejects cultural deficiency theories of Chicano crime and delinquency, and calls for a model that recognizes the relationship between structural determinism and the role of competing world views.

Montoya, Margaret E., Law and Language(s): Image, Integration and Innovation, 7 La Raza L.J. 147 (1994). (Themes 2, 5, 9, 12, 15).

Proposes that adherence to traditional language norms in legal education tends to impoverish and distort legal discourse as well as coerce cultural assimilation of linguistic outsiders. Uses narrative analysis to highlight ways in which monolingual and monocultural discourse devalues the Spanish language. Calls for the use of metissage or "linguistic code-switching" in the classroom to create discursive space for telling stories that combine dominant language with "outlaw languages," thereby giving voice to bicultural clients and support to Latina/o resistance of cultural-linguistic hegemony.

Montoya, Margaret E., Máscaras, Trenzas, y Greñas: Un/masking the Self While Un/braiding Latina Stories and Legal Discourse, 17 Harv. Women's L.J. 185 (1994), concurrently published in 15 ChicanoLatino L. Rev. 1 (1994). (Themes 2, 4, 6, 7, 12, 15).

Uses personal narratives to show how outsiders, particularly Latinas/os, adopt varions máscaras (masks) to construct a public persona acceptable to the dominant culture. Reveals how this process of acculturation disguises ethnic and racial difference, simultaneously providing defenses against racism and subordinating Latinas/os as they lose touch with their personal selves. Braids the personal and the academic voice, legal and interdisciplinary scholarship, English and Spanish, to illustrate how bicultural and bilingual storytelling becomes a discursive technique for resisting 
cultural-linguistic domination through both personal and collective redefinition of the Latina/o self.

Moran, Rachel F., Bilingual Education as a Status Conflict, 75 Calif. L. Rev. 321 (1987). (Themes 1, 3, 5, 9, 14).

Uses status conflict analysis to show that proponents and critics of bilingual education programs have used language as a vehicle to perpetuate or enhance the status of their own cultures, customs, and values. Shows how the debate has been fueled not only by concerns about governmental allocation of educational resources, but also by desires to accord symbolic cultural deference to a particular way of life. Describes how the response of English-only advocates represents a backlash to bilingual education victories and seeks to preserve the status of Anglo culture from increasing encroachment by linguistic minorities. Demonstrates that, because of requirements to substitute language barriers as a proxy for race, Latino and Asian efforts to establish bilingual education programs are diluted when litigated under multiple-issue omnibus civil rights acts primarily designed to redress discrimination against African Americans.

Moran, Rachel F., Demography and Distrust: The Latino Challenge to Civil Rights and Immigration Policy in the 1990s and Beyond, 8 La Raza L.J. 1 (1995). (Themes 3, 8, 9, 13, 14).

Reviews traditional civil rights and immigration advocacy models and examines their potential limitations for Latinos. Shows that the civil rights framework is rooted in African-American demands, and demonstrates how Latinos have tried to broaden this framework to include bilingualism and community control of neighborhood schools. Argues that coalition-building is essential among the civil rights community to achieve equal educational opportunities. Points out that the global economy has heightened awareness of U.S. immigration policy. Examines the traditional model of European immigration as a long-term, permanent commitment to the U.S., forswearing allegiance to the mother country. Contrasts the Latino experience, which includes ongoing contact with home countries and development of a transnational identity rather than exclusive loyalty to the U.S. Suggests that solutions to immigration issues may emerge from international human rights law, international labor organizing, and efforts to assure the job security of the U.S. workforce. 
Moran, Rachel F., Of Democracy, Devaluation, and Bilingual Education, 26 Creighton L. Rev. 255 (1993). (Themes 1, 5, 9, 12).

Charges that federal policymakers of bilingual education focus too narrowly on the relationship between the individual and the state, overlooking and undervaluing the importance of linguistic and cultural groups in influencing personal identity and the development of interpersonal skills. Stemming from two models of democratic decision making, this undervaluation takes the form of special interest bargaining (aggregating individual preferences), and "technocratic" republicanism (relying on technocrats to identify the public interest), thereby limiting group input and increasing factionalization. Proposes an ethic of pluralism that affirmatively values linguistic and cultural groups and explores how current governmental strategies for intervention might be restructured to accommodate parent and student participation.

Moran, Rachel F., The Politics of Discretion: Federal Intervention in Bilingual Education, 76 Calif. L. Rev. 1249 (1988). (Theme 1, 9).

Posits that the intractability of the bilingual education controversy rests on the allocation of discretion to make educational policy. Examines four major groups-parents and community leaders, educational experts, federal officials, and English-only reformers-that have challenged state and local educators' discretionary prerogatives in developing curricula for linguistic minority students. Describes the deficiencies of each group's position and the type of intervention each proposes. Reviews the history of federal intervention in bilingual education, revealing conflicting assertions about the proper allocation of discretion in the decision making process. Examines three approaches to the allocation of discretion and assesses how they have shaped policy. Suggests an alternative framework that examines the organizational structure of schools and the necessary comprehensiveness of reforms.

Moran, Rachel F., Unrepresented, 55 Representations 139 (1996). (Themes 1, 3, 5, 11).

Develops a framework for understanding Latinos' relative invisibility in many policy issues, questioning why affirmative action debates are cast in black/white terms-especially in states such as California where Latinos are the largest minority. Asserts that Latinos/as have been underrepresented because their identity and entitlements have been undercut by two competing policy models: civil rights and immigration. Shows how Latinos are required 
to conform to a black experience under the civil rights model, and to a white experience under the immigration model, rendering progress difficult under either approach. Concludes that Latinos/as face a challenge in merging these models in ways that mutually reinforce the definition of their identity and history.

Navarrette, Ruben, Jr., A Darker Shade of Crimson: Odyssey of a Harvard Chicano (1993). (Theme 8, 17).

In the tradition of Richard Rodriguez and Stephen Carter, criticizes affirmative action as serving primarily high achievers who need it least and suffer discrimination because of it. Reflects on entering Harvard in 1985 as one of only thirty five Mexican Americans, and attendant feelings of privilege, loneliness, alienation, and guilt. Describes pressures by other Harvard Chicanos/as to abandon assimilationist ways and embrace ethnic authenticity. Argues that left-oriented groupthink can be harmful and dehumanizing.

Oboler, Suzanne, Ethnic Labels, Latino Lives: Identity and the Politics of (Re)Presentation in the United States (1995). (Themes 4, 5, 6, 8, 11).

Describes the origin and historical use of the ethnic label "Hispanic." Argues that homogeneous characterization as Hispanic affects the self-perception of the various groups that have emigrated to the United States from Latin America since passage of the Immigration Law of 1965. Explains that each group that emigrates from Latin America does so as a result of varying historical processes and during different periods in U.S. history. Addresses the immigration of Latin Americans and how Latino identity in the United States is constructed. Concludes that ethnic labeling determines the distribution of resources and opportunities and the inclusion or exclusion of a group in the political process.

Olivas, Michael A., "Breaking the Law" on Principle: An Essay on Lawyers' Dilemmas, Unpopular Causes, and Legal Regimes, 52 U. Pitt. L. Rev. 815 (1991). (Themes 1, 5, 12).

Uses the example of Oscar "Zeta" Acosta's work to argue for a new form of lawyering on behalf of the radically disenfranchised. Argues that law schools, judges, and other legal institutions systematically ignore plain cases of injustice such as the plight of Central American children locked up in detention centers for long periods of time away from their families. Urges that U.S. lawyers and scholars confront such cases of injustice, naming them and publicizing them before worldwide constituencies. 
Olivas, Michael A., The Chronicles, My Grandfather's Stories, and Immigration Law: The Slave Traders as Racial History, 34 St. Louis U. L.J. 425 (1990). (Themes 1, 2, 5).

Argues that Derrick Bell's Chronicle of the Space Traders, ${ }^{21}$ in which the United States agrees to sell all citizens of African descent in return for gifts offered by interterrestrial traders is, in fact, borne out by Chicano and Native-American experience. Cites forcible removal, the Bracero program, mistreatment of Chicano youth and laborers, and racist immigration quotas to show that the rights of people of color are always sold for pecuniary or psychic advantage. Recounts stories told by his grandfather to illustrate how storytelling by outgroups serves to enhance solidarity and enable survival of the mistreated, and to cast doubt on comforting majoritarian myths used to justify race-trading and other forms of injustice.

Olivas, Michael A., The Education of Latino Lawyers: An Essay on Crop Cultivation, 14 Chicano-Latino L. Rev. 117 (1994). (Themes 1, 4, 12).

Shows that U.S. law schools still contain relatively small numbers of Latino/a students and faculty despite two decades of affirmative action. Argues that this is a demand, not a supply problem because Latino/a teaching candidates, as a group, have better credentials than the average of those hired, and because U.S. law schools control the size of the applicant pool by the students they admit and by encouraging certain teaching candidates but not others. Suggests measures law schools may take to improve this situation.

Olivas, Michael A., Legal Norms in Law School Admissions: An Essay on Parallel Universes, 42 J. Legal Educ. 103 (1992). (Themes 1, 2, 5, 12).

Argues that recent criticism of dual-track diversity admissions plans in higher education as tantamount to illegitimate race-norming are ahistorical and misguided, resting on historical amnesia that overlooks a legacy of separate but equal schools, underfunded black colleges, and universities that totally excluded blacks and other students of color even after Brown v. Board of Education. ${ }^{22}$ Takes special issue with Lino Graglia's argument that affirmative action is

21. Derrick Bell, After We're Gone: Prudent Speculations on America in a Post-Racial Epoch, 34 ST. Louis U. L.J. 393 (1990).

22. 347 U.S. 483 (1954). 
unfair to deserving whites, pointing out that little displacement occurs and that the minorities who are admitted are fully qualified. Moreover, white beneficiaries of racial practices "often assume that they reached their station in life on the merits," when in fact they benefit from previous exclusion of competitors of color and from a misapplication of standardized test scores.

Omi, Michael \& Howard Winant, Racial Formation in the United States: From the 1960 s to the 1980 s (1986). (Themes 1, 4, 5).

Focuses on the centrality of race in U.S. society in creating mass movements and forming state and foreign policy. Shows how challenges to ethnicity theory, dominant since the 1940s, have come from class-based and nation-based theories of race. Proposes an alternative theory of race based on racial formation and the socially based trajectory of racial politics. Analyzes changes in racial meaning and politics and how social movements around race confront power structures. Criticizes conservatives for taking away gains made by the civil rights movement, in the guise of having a "colorblind" society. Argues that race is not objective and fixed, but rather a web of social meanings that shifts according to the political agendas of the time.

Ontiveros, Maria L., Fictionalizing Harassment-Disclosing the Truth, 93 Mich. L. Rev. 1373 (1995). (Themes 2, 6, 7).

Contrasts two different narratives of sexual harassment found in U.S. society: the "dominant story" told from a fictitious white male perspective in Michael Crichton's Disclosure, ${ }^{23}$ and the "marginalized story" presented by first-person accounts of approximately fifty women in Celia Morris' Bearing Witness. ${ }^{24}$ Argues that oppositional, nontraditional stories are important for what they teach about sexual harassment in U.S. society, and can thus be a crncial means of reshaping current sexual harassment doctrine. Shows how unconscious racism against women of color is almost always inseparable from the harassment perpetrated against them, and must be taken into account by legal scholars and judges in developing flexible categories within employment discrimination law to curb harassment.

23. Michael Crichton, Disclosure (1994).

24. Celia Morris, Bearing Witness (1994). 
Ontiveros, Maria L., Rosa Lopez, David Letterman, Christopher Darden, and Me: Issues of Gender, Ethnicity, and Class in Evaluating Witness Credibility, 6 Hastings Women's L.J. 135 (1995). (Themes 6, 7, 8, 9, 16).

Criticizes tactics of the prosecution during the O. J. Simpson trial to discredit Rosa Lopez, as well as the biased treatment of her testimony by the media. Argues that Lopez's credibility would not have been put so much into question if better translations had been made of phrases that change ineaning depending on the Spanish-speaking country in which they are used. Demonstrates that the court's lack of awareness of cultural differences, such as name usage, led to misunderstandings about Lopez's seemingly self-contradictory statements. Shows that without high-quality translation, cultural nuance- and hence accurate fact-finding - are easily lost in criminal trials when a key participant is a nnember of another culture. Shows that the media were biased against Lopez because of her status as a Latina and as a working class woinan.

Ontiveros, Maria L., Three Perspectives on Workplace Harassment of Woinen of Color, 23 Golden Gate U. L. Rev. 817 (1993). (Themes 1, 5, $6,7)$.

Shows how racism and sexism combine in the experience of women workers of color harassed in the workplace and offers a framework for addressing it. Reasons that these two forces work together to create a unitary harm, from the perspective of both the harasser and the victim. Proposes that reform take the guise of either modification of existing rules governing sexual harassment or creation of a new cause of action for woinen of color victimized in the workplace.

Ontiveros, Maria L., To Help Those Most in Need: Undocumented Workers' Rights and Remedies Under Title VII, 20 N.Y.U. Rev. L. \& Soc. Change 607 (1994). (Themes 3, 6, 11).

Examines a case of statutory intersectionality-the difficulties encountered by illegal immigrants in enforcing rights against discrimination under Title VII since passage of the Immigration Reform and Control Act (IRCA). Describes the nature of discrimination faced by undocumented workers. Demonstrates how IRCA has severely limited the ability of undocumented workers to recover under Title VII because many remedies, such as reinstatement, frontpay, and backpay, are severely restricted if the employee is not a legal resident. Explains that as a result, many undocumented 
workers, many of whom are Latinas, are severely abused-sexually, emotionally, and economically-because their employers do not fear legal retribution. Argues that the purposes of both IRCA and Title VII would be better served if remedies were available to undocumented workers: enployer abuses would stop and less illegal immigration would occur if einployers were forced to internalize fully the costs of hiring workers and treating them decently.

Oquendo, Angel R., Re-Imagining the Latino/a Race, 12 Harv. BlackLetter J. 93 (1995). (Themes 1, 3, 5, 8).

Discusses terminology and alternative classifications for the Latino/a race, including how the group should see itself and be seen for various purposes, including the U.S. Census, and for achieving grassroots solidarity. Condemns subcategories, such as white or black Hispanic, as divisive, and urges that the "Inaterial" view of race be dropped.

Our Next Race Question: The Uneasiness Between Blacks and Latinos, Harper's, Apr. 1996, at 55. (Themes 6, 8, 14).

Colloquoy among Jorge Klor de Alva, Earl Shorris, and Cornel West examining the tension between blacks and Latinos in their selfidentification and perceptions of each other. Shows how some Latinos think of blacks as Anglos because of their high degree of identification with American culture, while some blacks think lightskinned Latinos receive privileged treatment by the dominant white community. Debates whether programs such as affirmative action work equally well for blacks and Latinos. Explores the conflicts between the two groups and their inability to work together because of perceived unequal treatment and the perception that they are in competition for social programs. Suggests that the next issue on the civil rights agenda will be black-brown, not black-white, relations.

Padilla, Felix M., Latino Ethnic Consciousness: The Case of Mexican Americans and Puerto Ricans in Chicago (1985). (Themes 4, 8, 11).

Examines the external and internal factors that shape a common "Latino-conscious" behavior and identity separate from individual ethnic identities of Mexican Americans, Puerto Ricans, Cubans, and other Spanish-speaking groups in Chicago. Uses historical data and interviews of community leaders from the early 1970s to 1985 . Shows how shared experiences of inequality common to each group provide the structural framework that shapes the formation of Latino 
ethnic consciousness and aids mobilization to realize social and political goals.

Padilla, Felix M., Puerto Rican Chicago (1987). (Themes 4, 6, 8, 10, 14, 15, 16).

Analyzes changes in Puerto Rican ethno-consciousness from the period of the U.S. takeover in 1898, when a stigmatized status of racial mferiority replaced an emerging nationalism, to present-day ethnic consciousness. Argues that these changes in consciousness result from the internal colonialism of Puerto Ricans within the United States, and the interaction between Puerto Ricans and the dominant society. Proposes guidelines for mobilizing the Puerto Rican community and calls for a Latino-black coalition to address issues of social and economic justice.

Paredes, Américo, "With His Pistol in His Hand," A Border Ballad and 1ts Hero (1958). (Themes 2, 4, 10, 16).

Situates the legend of Gregorio Cortez historically, and describes how the demarcation of the border between Mexico and the United States after the 1848 Treaty of Guadalupe Hidalgo ended a way of life. Contrasts attitudes of Mexicans and Anglo-Texans toward each other, as found in and perpetuated by war propaganda, verse, the writings of historians Walter Prescott Webb and J. Frank Dobie, and the exploits of the Texas Rangers. Retells and analyzes the corrido of Gregorio Cortez and its variants, likening it to other warrior-hero ballads of border conflict, such as those that celebrated Scottish resistance to Anglo hegemony.

Perea, Juan F., The Black/White Binary Paradigm of Race: The "Normal Science" of American Racial Thought, 85 Calif. L. Rev. 1213 (1997), 10 La Raza L.J. 127 (1997). (Themes 1, 3, 5, 14).

Argues that the civil rights movement's "normal science" (i.e., the dominant mode of thinking about race) is wedded to a black/white paradigm in which minority groups other than African Americans are either treated as variants of blacks or neglected altogether. Illustrates this treatment in the works of leading scholars of race and shows how adherence to the binary paradigm prevents U.S. race-remedies law from doing full justice, while impeding coalitions between blacks and other groups. Argues for an expanded paradigm that incorporates the experiences of Latinos and Asians. 
Perea, Juan F., Demography and Distrust: An Essay on American Languages, Cultural Pluralism, and Official English, 77 Minn. L. Rev. 269 (1992). (Themes 1, 3, 5, 9).

Examines the paradoxical tension in the United States between cultural pluralism and the demand for conformity. Reveals the persistence of myths such as that of linguistic homogeneity, which allows many people to perceive English as the only true American language, and genuine "American" identity as synonymous with the dominant Anglo culture. Challenges these myths by using U.S. legal history to show that cultural pluralism and linguistic diversity were explicitly recognized at the founding of the U.S. republic. Recounts how nativism comes to the fore during periods of national stress and argues that the official English movement is yet another stage in nativist attempts to outlaw people who differ from the core culture-in this case, by excluding Latino peoples from the definition of American identity. Examines how using language as a proxy for exclusion on the basis of national origin violates principles of equal protection.

Perea, Juan F., Ethnicity and Prejudice: Reevaluating "National Origin" Discrimination Under Title VII, 35 Wm. \& Mary L. Rev. 805 (1994). (Themes 3, 5, 8, 9, 16).

Argues that statutory language in employment discrimination law should be broadened from national origin to include perceptible ethnic traits such as language, accent, surname, and appearance. Reveals how courts have allowed ethnic discrimination, particularly in cases that turned on languages other than English, accents, or lack of proficiency in English. Concludes that explicit protection of ethnic traits would reduce incorrect and inconsistent court decisions and better protect the interests of a pluralistic society.

Perea, Juan F., Ethnicity and the Constitution: Beyond the Black and White Binary Constitution, 36 Wm. \& Mary L. Rev. 571 (1995). (Themes $1,3,5,8,9$ ).

Critiques the black/white dichotomy in civil rights law for failing to address the situations of all people of color. As a result, courts recognize national origin and ancestry in enforcing the Equal Protection Clause but often not ethnicity, which includes traits such as "language, religion, shared history, tradition, values, and symbols." Illustrates the problem by means of the Supreme Court's 
holding in Hernandez v. New York, ${ }^{25}$ which allowed prosecutors to use peremptory challenges against potential bilingual jurors whom the prosecutors felt would not strictly follow the court's official interpretation of non-English speaking witnesses' testimony. Explains that by not recognizing the ethnicity trait of language, the Court sanctioned discrimination against bilingual Latinos/as. Concludes that forced assimilation and denial of ethnic differences-even in pursuit of "colorblindness"-is tantamount to upholding white privilege, since white ethnicity is the standard against which deviancy and ethnic variance are judged.

Perea, Juan F., Los Olvidados: On the Making of Invisible People, 70 N.Y.U. L. Rev. 965 (1995). (Themes 1, 5, 9, 15).

Describes the process of "symbolic deportation," by which Latino people are rendered politically invisible by the foreignness of their language and culture. Shows how fear of Spanish by Englishonly speakers, and a parallel fear by Latinos/as of being identified with the Spanish language, are the primary causes of "death by English"- a denial of one's Latino/a identity and concomitant reconfiguration of identity with the dominant Anglo culture. Analyzes the relative lack of positive public identity and legitimacy for Latinos/as in the U.S. in three interdependent settings: the near absence of Latinos/as from popular media presentation and scholarly treatment, the American Framers' conception of a white nation without racial mixture, and the role of law and "national origin" in creating a false and stigmatizing image of foreignness for the Latino people.

Piatt, Bill, Attorney as Interpreter: A Return to Babble, 20 N.M. L. Rev. 1 (1990). (Themes 3, 5, 9).

Examines the ethical problems facing clients and attorneyinterpreters in judicial proceedings. Stndies the potential harm this relationship imposes on the client, the attorney, and the administration of justice, claiming that none of these interests is properly served by an attorney-interpreter. Discusses a client's right to an interpreter, the implementation of this right, Sixth Amendment concerns regarding effective counsel and confrontation of witnesses, and due process and equal protection concerns. Stresses that if attorneys continue to act as interpreters for Latinos/as (and other language minorities), clients will be forced to defend themselves without the traditional legal safeguards afforded to others.

25. 500 U.S. 352 (1991). 
Piatt, Bill, Black and Brown in America: The Case for Cooperation (1997). (Themes 4, 8, 14).

Examines similarities and differences between Latinos and African Americans, addressing such issues as slavery and immigration, racial and ethnic identity, competition for jobs, education and affirmative action, language barriers, gangs, and voting. Offers proposals for racial harmony and urges coalition building, cooperation, and understanding.

Piatt, Bill, Born as Second Class Citizens in the U.S.A.: Children of Undocumented Parents, 63 Notre Dame L. Rev. 35 (1988). (Theme 3, 11).

Explores validity of sanctions used against U.S. citizen children for the purpose of discouraging illegal/undocumented immigrant parents from staying in or coming back to the United States. Examines the dichotomy between the courts' willingness to intervene to prevent officials from making the educational and economic circumstances of these children more difficult because of their parents' undocumented status, and the courts' lack of intervention as officials make those circumstances more difficult when the children's parents are deported. Claims that courts should recognize that either choice-remaining parentless in the United States or staying with their deported parents in a family unit-is a deprivation that creates "extreme hardship" to the child as a matter of law. Suggests that legislative remedies be created, that public assistance be increased, and that courts recognize equal protection and due process violations of these children's rights.

Piatt, Bill, ¿Only English? Law and Language Policy in the United States (1990). (Theme 3, 9).

- Examines how the U.S. legal system has evolved, against a historical background of periodic nativist attempts to limit multilingualism, to the current recognition (albeit inconsistent) of langnage rights in a variety of settings. Argues that these strands provide a starting point for recognition of a right to maintain and use native languages other than English. Encourages a policy of "limited official bilingnalism" when access to basic human needs is at issue, and one of "limited official monolingualism" when the immediate safety of persons or property requires communications in a standard language understood by the majority. Holds that individuals should be given the freedom to use their language of choice in the vast majority of other human communications, with the attendant right to have 
recourse to legal remedies for infringement of that choice. Argues that this recognition will advance both domestic and international relations and protect culture and personality, both of which turn, in large part, on language.

Portes, Alejandro, \& Alex Stepick, City on the Edge: The Transformation of Miami (1993). (Themes 4, 8, 11, 14).

Profile of Miami, based on statistical data, interviews, observations, anecdotes, and newspaper articles. Shows how, since 1960, political events have shaped Miami's development as a major urban center. Gives histories of groups, predominantly Latino (Cubans, Haitians, Nicaraguans) who now make up the majority of the population, and discusses intergroup conflicts. Predicts that assimilation may accelerate after Castro's demise.

Ramirez, Deborah A,, Excluded Voices: The Disenfranchisement of Ethnic Groups from Jury Service, 1993 Wis. L. Rev. 761. (Themes 4, 9).

Discusses Hernandez v. New York, ${ }^{26}$ in which the Supreme Court upheld the exclusion of a bilingual Spanish-speaking juror on the ground that the juror would listen not to the official version of Spanish-language testimony offered by the translator, but rather to the Spanish-speaking witnesses themselves. Uses social science to show that a bilingual juror will always be unable to ignore the firsthand testimony and concentrate only on the interpreted version, and that Hernandez effectively disenfranchises Latinos/as because of the super-correlation between race and language in the Latino community.

Ramirez, Deborah A., The Mixed Jury and the Ancient Custom of Trial by Jnry De Medietate Linguae: A History and a Proposal for Change, 74 B.U. L. Rev. 777 (1994). (Themes 1, 5, 6).

Reviews recent jury selection cases to show that the Supreme Court pursues an abstract and misguided ideal of color-blindness, thus impairing the right of many defendants to an impartial jury. Exaltation of the right of citizens to sit on juries over that of criminal defendants to fair treatment introduces the greatest unfairness in cases, like that of the police officers accused of beating Rodney King, which have a racial dimension. Urges a policy of mixed juries in such cases, showing that this policy has roots in the ancient

26. 500 U.S. 352 (1991). 
English custom of a jury de medietate linguae, according to which civil trials between Jews, for example, would take place before a separate Jewish tribunal. Shows that this policy was followed by the early U.S. colonials in cases concerning Indians, and argues that its application today would enable courts to render better justice. Defends the proposal in the face of various objections, including the objection that it is premised on an essentialist view of minority experience.

Ramirez, Deborah A., Multicultural Empowerment: It's Not Just Black and White Anymore, 47 Stan. L. Rev. 957 (1995). (Themes 1, 3, 5, 14).

Describes demographic trends showing the proportion of people of color in the United States has increased in the last thirty years, while the percentage of African Americans has decreased. Analyzes whether race-based remedies originally designed to address discrimination against blacks can effectively redress discrimination against non-black people of color. Examines the inability of such remedies to solve conflicts among minority groups competing for social resources. Advocates a "multicultural empowerment" paradigm allowing individuals to self-identify by race as well as by other factors such as language, poverty, sexual orientation, or disability. Concludes that multicultural empowerment can be crucial to creating new policies empowering minority groups without resorting to a system of racial classifications, and to fostering transracial alliances.

Rangel, Jorge C. \& Carlos M. Alcala, Project Report: De Jure Segregation of Chicanos in Texas Schools, 7 Harv. C.R.-C.L. L. Rev. 307 (1972). (Themes 1, 3, 5, 16).

Reports invidious discrimination against Chicanos/as at all levels of Texas society, including beauty shops, drugstores, restaurants, swimming pools, movie theaters, and in the administration of justice. Focusing on public education, finds that contemporary pattern of school attendance is directly traceable to former de jure segregation and warrants de jure relief. Uses maps, charts, and statistics to trace intentional pattern of segregating Mexican schoolchildren in inferior schools. Argues that attorueys litigating Chicano desegregation suits have mistakenly pursued an "other white" strategy rather than challenging racist patterns of school assiguments directly. Argues that Mexican Americans should be afforded suspect-class status for purposes of judicial review of school decisions and discusses theories of relief. 
Recovering the U.S. Hispanic Literature Heritage (Ramón A. Gutiérrez \& Genaro Padilla eds., 1993). (Themes 4, 6, 8, 16).

Presents essays growing out of the first two conferences of Recovering the U.S. Hispanic Literary Heritage project, a ten-year research, restoration, and publication program that includes preserving primary documents and establishing a database and archives of literary works by Chicano, Mexican, Cuban, Puerto Rican, and Central and South American writers of the United States. Essays analyze this body of work, tracing its national and regional complexity in a celebration of hybridity, intertextuality, and polyvocality. Subjects addressed include literary histories and communities, genres, and canon formation. Includes "The UCLA Bibliographic Survey of Mexican-American Literary Culture, 1821-1945: An Overview," by Ramón A. Gutiérrez.

Rieff, David, Los Angeles: Capital of the Third World (1991). (Themes $6,8,11,14,16$ ).

Revisits Los Angeles, noting its change from a Pacific coast paradise that idealized its Spanish colonial heritage (and relocated its Mexican-American population) to a complex metropolis comprised of more than a hundred ethnic groups. Shows the contradiction in the way a money-conscious, servant-dependent society enjoys a superficial cosmopolitanism while the largely Latino and Asian "third world" immigrant population struggles to survive and cope with intragroup conflicts.

Rivera, Jenny, Domestic Violence Against Latinas by Latino Males: An Analysis of Race, National Origin, and Gender Differentials, 14 B.C. Third World L.J. 231 (1994). (Themes 4, 5, 6, 7, 16).

Examines the stereotype of Latino machismo, which tends to legitimize - both within and without the Latino community-domestic violence as a cultural norm, and to excuse intraracial violence against Latinas. Rejects the use of the "cultural defense." Presents data on the intersection of race and ethnicity and the ways in which the impoverished political and economic stance of Latinas causes them to respond to domestic violence less forcefully than either black or white women. Explores inadequacies of responses to violence against Latinas by legislation, law enforcement officials, the criminal justice system, and social service programs. Concludes that Latinas are best situated to describe their own predicament and that a community empowerment model using the resources of Latino 
communities is best suited to address domestic violence against Latinas.

Rivera, Jenny, The Politics of Invisibility, 3 Geo. J. on Fighting Poverty 61 (1995). (Themes 4, 6, 7).

Argues that Latinas have carried much of the burden of the poverty and inequality of Latinos/as in the United States. Calls for an anti-violence agenda that addresses the experience of Latinas and other women of color, focusing on abuse by law enforcement officers and the problems Latinas experience in the current shelter system. Points out the need for carefully crafted legislation that takes account of the needs and resources of Latinas and other women of color.

Rivera, Jenny, The Violence Against Women Act and the Construction of Multiple Consciousness in the Civil Rights and Feminist Movements, 4 J.L. \& Pol'y 463 (1996). (Themes 1, 6, 7).

Urges coalition between civil rights activists and feminists in order better to protect intimate partners against violence. Argues that despite histories of conflict and mutual distrust, the two groups should be able to converge over enforcement of the federal Violence Against Women Act by adopting a perspective of multipleconsciousness. Doing so will increase the Act's ability to address violence against women of color and immigrants by assuring that the unique features of domestic violence in their communities are recognized and confronted.

Rodriguez, Luis J., Always Running: La Vida Loca-Gang Days in L.A. (1993). (Theme 2, 4).

The author, a gang member in the Las Lomas barrio of South Central Los Angeles in the late 1960s and early 1970s, gives a chilling account of ten years of la vida loca-the barrio gang experience. Begins with a brief history of his family's migration to Los Angeles, but primarily focuses on his teenage years in the barrio and its schools, and running from the law. Suggests that the inner city cycle of gang violence and youth will continue to thrive unless economic and social change is embraced so that Chicano youth are able to express solidarity and celebrate their culture in positive ways. 
Rodriguez, Richard, Days of Obligation: An Argument With My Mexican Father (1992). (Themes 6, 8, 17).

Traditionalist-conservative essayist comes to terms with his own background and cultural identity. Chapters (many reprinted from various magazines and journals) deal with issues of modernity, mestizaje (racial mixture), and the conflicted role of the Englishspeaking, cosmopolitan Latino intellectual. Discusses gay identity, attachment to Mexico, class differences within the Mexican-American community, Catholicism, and the meaning of California and the border.

Rodriguez, Richard, Hunger of Memory: The Education of Richard Rodriguez (1982). (Themes 2, 6, 15, 17).

Autobiographical account of the writer's early years. Includes ambivalent or negative thoughts on bilingualism, affirmative action, cultural nationalism, and other premises of the political left. Provides more sympathetic treatment of the role of Latino family and of preserving ties and heritage of Mexican past.

Roithmayr, Daria, Deconstructing the Distinction Between Bias and Merit, , 85 Calif. L. Rev. 1449 (1997), 10 La Raza L.J. 363 (1997). (Themes 1, 5).

Responds to Farber and Sherry's defense of merit ${ }^{27}$ by showing that, though merit and bias appear to be polar opposites, they instead partake of and even collapse into each other on analysis. Argues that standard measures of merit, such as the LSAT, reflect what the dominant group knows and values, while race-based affirmative action programs enable formerly excluded groups to participate in the construction of new standards of merit. Urges that the misdirected focus on merit in recent scholarship exemplifies color-blind Enlightenment political philosophy that is flawed and injurious to outgroups of color.

Romany, Celina, Ain't I a Feminist?, 4 Yale J.L. \& Feminism 23 (1991). (Themes 1, 6, 7).

Criticizes essentialism in feminist theory for offering an inadequate theory of oppression. A monocausal emphasis on gender short-changes those who suffer on account of race, ethnicity, and

27. Daniel A. Farber \& Suzanna Sherry, Is the Radical Critique of Merit Anti-Semitic?, 83 Calif. L. Rev. 853 (1995); Daniel A. Farber \& Suzanna Sherry, Beyond All Reason: Radical Multiculturalism, LaW ANd ANTI-SEmitism (1997). 
class in addition to gender. Illustrates reductionism in the work of four prominent feminists and gives examples of legal problems that cannot yield to analysis in terms of only one variable. Argues that the cure for such simplistic thinking lies in heeding Third World cultural theorists, particularly ones who write about border phenomena and who critique nationality.

Romany, Celina, Women as Aliens: A Femninist Critique of the Public/Private Distinction in International Human Rights Law, 6 Harv. Hum. Rts. J. 87 (1993). (Themes 1, 7, 13).

Argues that international human rights discourse has done little for women. Illustrates thesis with a discussion of wife murders in Brazil and how the human rights framework construes the civil and political rights of individuals as belonging to the public realm, while failing to protect rights for women in familial relationships. Though women are still "aliens" in international law, this arena may yet develop new norms of state responsibility for human rights violations of women. Calls for international law to incorporate a dialogic framework that would broaden patriarchal narrative to include the voices and concerus of women.

Romero, Leo, Richard Delgado, \& Cruz Reynoso, The Legal Education of Chicano Students: A Study in Mutual Accommodation and Cultural Conflict, 5 N.M. L. Rev. 177 (1975). (Theme 12).

Explores dissonance afflicting Chicanos/as in various aspects of legal education including the Socratic method, the culture of the classroom, examinations, and admissions policy. Suggests that rather than expecting students of color to accoinmodate to inajoritarian practices, legal institutions would benefit by moving in the opposite direction, toward a more inclusive approach that recognizes a plurality of learning styles and aspirations.

Rosaldo, Renato, Culture \& Truth: The Reinaking of Social Analysis (1989). (Themes 1, 4, 5, 10).

Uses ethnographic studies to scrutinize how anthropology has undergone a radical transformation since the 1960s. Historical processes including decolonization, immigration and intercultural borrowing, the civil rights movement, and the emergence of global markets have produced a decentering of objectivism and a shift to plural forms of analysis. Contends that critical anthropology requires a reworking of the classic concept of culture, which has engendered notions of the possibility of passive observation 
and cultural separateness, to recognize that anthropologists are positioned social actors whose interpretations of culture are in turn acted upon by the subjects whom they observe. Examines three Chicano warrior-hero narratives-Américo Paredes' With a Pistol in His Hand, ${ }^{28}$ Ernesto Galarza's Barrio Boy, ${ }^{29}$ and Sandra Cisneros' The House on Mango Street $t^{30}$-to show their value as analyses of the concept of culture in which the portrayal of Chicano/a identity shifts from an emphasis on cultural purity to mockery to survival struggles at social border zones. Posits that the hybridity and fluidity of border cultures renders them sites of creative cultural production.

Rosenbaum, Robert J., Mexicano Resistance in the Southwest: "The Sacred Right of Self-Preservation" (1981). (Themes 4, 5, 10).

Tells of the ways poor Mexicano people in the Southwest, especially New Mexico, organized to resist Anglo encroachment. Focuses particularly on Las Gorras Blancas and similar insurgent organizations that attacked americanos and rich mexicanos who acted like Anglos. Discusses border disputes, L.A. riots, nationalist parties, fence-cutters, and rebels like Gregorio Cortez (whose exploits are captured in myth, song, and a recent film). Describes tensions between los pobres and more assimilated Mexican-American "progressives" who sought reform through conventional means. Sees the unending struggle of Mexican Americans in the Southwest as an aspect of the right of self-preservation.

Ruiz, Vicki L., By the Day or Week: Mexicana Domestic Workers in El Paso, in "To Toil the Livelong Day": America's Women at Work, 1780-1980, 269 (Carol Groneman \& Mary Beth Norton eds., 1987). (Themes 2, 4, 6, 7).

Uses oral history to describe the plight of Mexican women seeking domestic employment in Texas. Shows how these women, although central to the region's economy, are exploited. Describes their efforts to resist low wages, sexual abuse, and loss of dignity. Examines patronizing attitudes of many Anglo homemakers, some of whom believe they are doing the women a favor by hiring them to perform

28. Américo Paredes, "With his Pistol in his Hand," a Border Ballad and its Hero (1958).

29. ERnesto Galarza, Barrio Boy (1971). In addition to his well-known novel, Galarza wrote penetrating critiques of the bracero program, namely SPIDERS IN THE HouSE AND WORKERS IN THE FIELD (1970); MERChaNTS OF LABOR (1964); and FARMWORKERS AND Agribusiness IN CALIFORNIA, 1947-1960 (1977).

30. Sandra Cisneros, The House on Mango Street (1983). 
menial work. Notes that some Hispanic homeowners treat them no better. Shows how a surplus labor market works against efforts to improve working conditions and minimum wages for domestic workers.

Saldívar, José David, The Dialectics of Our America: Genealogy, Cultural Critique, and Literary History (1991). (Themes 2, 4, 6, 8, 10, 12).

Calls for development of an oppositional model of American literary history that embraces a postcolonial pan-Americanism and expands the canon to include Latin American and Chicano/a writing. Explores how the economic dependency of Latin countries on global capitalism shaped the way writers such as Jose Martí, Gabriel García Márquez, and Ntozake Shange have critiqued the Western metanarrative of progress. Shows how counterstorytellers such as Gloria Anzaldúa, Rolando Hinojosa, Arturo Islas, and Tomás Rivera address issues of power and class and race relations. Uses as an example Américo Paredes' recounting of the story of Gregorio Cortez as a challenge to the white supremacist rhetoric of Walter Prescott Webb. Explores how a number of Chicanos/as and Caribbean writers, such as Roberto Fernández Retamar, Emesto Galarza, and Cherrie Moraga, employ the Calibanic viewpoint of the oppressed as a technique of resistance. Shows how Richard Rodriguez's early work-highly successful with mainstream critics and readers-fails to go beyond angst to engagement with social change and critique of coercive dominant cultures.

San Juan, Epifanio Jr., Racial Formations/Critical Transformations: Articulations of Power in Ethnic and Racial Studies in the United States (1992). (Themes $1,4,6,12,14$ ).

Critiques the postmodern genealogical and deconstructive modes of racial analysis, noting that, while semiotic investigations have proven valuable, they have ultimately failed to bring about multiracial coalitions of resistance. Proposes a dialectical approach combining understandings of both history and consciousness in a way that allows racist discourse to be understood and challenged. Analyzes Arturo Islas' novel, The Rain God, ${ }^{31}$ to show how memorializing a people's resistance to coercion helps them cast off internal colonization and begin transforming dominant stories about themselves. Argues that race, not ethnicity, is the central determinant of

31. Arturo Islas, The Rain God (1984). 
power relations in the United States, and that its conceptual use can subvert the tendency of ethnicity theory to legitimize a pluralist but hierarchical social order.

Sánchez, George J., Becoming Mexican American: Ethnicity, Culture, and Identity in Chicano Los Angeles, 1900-1954 (1993). (Themes 4, $10,11,15)$.

Drawing on insights from cultural studies and other disciplines, examines the intricate process of cultural adjustment among Mexican rural immigrants to Los Angeles in the twentieth century. Argues that Chicano historians of the 1970s and early 1980s adopted a static bipolar model of opposing cultures, including retention of a Mexican way of life, or gradual acculturation into the American mainstream. Describes immigrant adaptation in family life, religion, music and popular culture, and at work. Analyzes how economic depression in the United States during the 1930s forged Mexican-American cultural identity by forcing examination of immigrants' desire and will to remain in the United States despite hostility and racism directed toward them. Concludes that Mexican Americans resolutely retained vestiges of native Mexican culture while at the same time inventing a uniquely American cultural identity.

Santos, Boaventura de Sousa, Toward a New Common Sense: Law, Science and Politics in the Paradigmatic Transition (1995). (Themes 4, 5).

Asserts that the paradigm of modernity has exhausted its potential for social emancipation, but remains socioculturally embedded due to inertia caused by the absorption of the emancipatory by the regulatory ideal. We stand today at the threshold of a paradigmatic transition that is characterized by two processes: the transformation of science into a form of production, and thus subject to regulation; and the elevation of law into a second-rate rationalizer of social life. Focusing on three interrelated forms of social regulation-power, knowledge, and law-and drawing on utopian thought, proposes a postmodern paradigm-an "emancipatory common sense"-to address struggles against global capitalist oppression. 
Saragoza, Alex M., Concepción R. Juarez, Abel Valenzuela, Jr., \& Oscar Gonzalez, History and Public Policy: Title VII and the Use of the Hispanic Classification, 5 La Raza L.J. 1 (1992). (Themes 1, 3, 5, 8).

Employs an incident in San Francisco to highlight the difficulties attending the use of the broad "Hispanic" classification in providing remedies for discrimination under Title VII and similar legislation. Points out that "Hispanics" contain Latin-American groups that are conservative and support U.S. military power in that region, Chicano and Puerto Rican nationalists and activists, and, arguably, persons of pure Spanish descent. Points out the dangers inherent in essentialist, nationalist discourse and the strategy of aggregation, as well as the risks of analogizing discrimination against Latinos to that directed against blacks.

Saunders, Myra K., California Legal History: A Review of Spanish and Mexican Legal Institutions, 87 Law Lib. J. 487 (1995). (Theme 5).

Offers overview and selective bibliography of primary and secondary sources on legal history of California before its occupation by the United States. Provides background of pre-conquest California history including description of legal and political institutions of the Spanish (1540-1821) and Mexican (1821-1846) periods. Explains that Anglo Americans rejected the Spanish/Mexican legal structure, which was based on community norms and employed conflict resolution, because they considered it inadequate for protecting their property interests. Consequently, many primary documents of that system are scattered, unindexed, and poorly preserved. Points out the Anglo-American bias of many secondary sources, particularly the earlier ones.

Shorris, Earl, Latinos: A Biography of the People (1992). (Themes 2, 4, $8,11,15,16)$.

Asserts that Latino assimilation can never be complete, showing that it is always tempered, and indeed shaped, by the fact that native culture persists-even if only in the physical qualities of "strangerness." Describes this process as a dialectic between the desire to be assimilated and nostalgia for a distinctive cultural identity. Outlines origins and particular histories of the major Latino subgroups in the United States, and questions the existence of a collective Latino identity. Uses stories of various Latino/a individuals and families, including his own, to examine themes of family, culture, language, art, education, politics, economics, poverty, racism, and immigration and assimilation. 
Stavans, Ilan, The Hispanic Condition: Reflections on Culture and Identity in America (1995). (Themes 4, 6, 8, 10, 11, 14, 15, 16).

Describes how the Latino cultural experience in America has been one of ambiguity-of "life in the hyphen." Shows that current experience differs from that of the past in that Americanization of Hispanics now takes place concurrently with the Hispanicization of the United States. Argues that, contrary to the Chicano movement of the 1960s, Latinos/as today are rejecting notions of a collective identity and instead embracing the cultural medley that makes up the contemporary Hispanic condition. Examines the multiple histories connecting and differentiating Latinos/as in the United States from those residing south of the border, and the ways in which their intellectual and artistic traditions reflect a plural culture with common foundations but different ancestral traditions. Predicts that in the next century U.S. preoccupation with multiculturalism will give way to a focus on acculturation and multiracialism.

Symposium: Latinos \& the Law: 20 Years of Legal Advocacy and Lessons for Advancement, 14 Chicano-Latino L. Rev. 1 (1994). (Themes 1, 2, 3, 4, 5, 9, 11, 12).

Series of short articles on developments in areas affecting Latinos/as, including environmental justice, criminal law, bilingualism, English-only rules, immigration, voting rights, and higher education. Authors include Ralph Abascal, Rodolfo Acuña, Leo Estrada, Robert García, John Martinez, Michael Olivas, and Bill Piatt.

Takaki, Ronald T., A Different Mirror: A History of Multicultural America (1993). (Themes 1, 4, 6, 11).

Expanding on his earlier work in Iron Cages ${ }^{32}$ and Strangers from a Different Shore, ${ }^{33}$ Takaki decenters the Anglocentric perspective on U.S. history and recounts stories of Chinese, Japanese, Native Americans, Mexican Americans, African Americans, Irish, and Russian Jews. Short chapters on Mexican Americans address conflicts with Anglos in the Southwest, immigration, and labor history. Shows how, though each group has a disparate history, the experience of racism is common to all.

32. Ronald T. Takaki, Iron Cages: Race and Culture in Nineteenth-Century AMERICA (1979).

33. Ronald T. TAKaki, Strangers from a Different Shore (1989). 
This Bridge Called My Back: Writings by Radical Women of Color (Cherríe Moraga \& Gloria Anzaldúa eds., 1981). (Themes 2, 6, 7, 15, 16).

Pathbreaking anthology and manifesto of feminism of color in the United States, containing poems, essays, letters, public statements, journal entries, and interviews by African-American, Latina, AsianAmerican, and Native-American women. Selections address childhood experiences dealing with the privilege of light skin; lifechanging events that inform feminist political theory of women of color; descriptions of the ways that white racism manifests itself in the women's movement; reflections on being a first-generation writer and on the standards by which Third World women writers' work must be judged; and statements of ways Third World radical feminism can bring about change in the lives of the oppressed. Includes selections by Norma Alarcón, Gloria Anzaldúa, Jo Carrillo, Aurora Levins Morales, Cherríe Moraga, Rosario Morales, Judit Moschkovich, and Mirtha Quintanales.

Toro, Luis Angel, “A People Distinct From Others": Race and Identity in Federal Indian Law and the Hispanic Classification in OMB Directive No. 15, 26 Tex. Tech. L. Rev. 1219 (1995). (Themes 1, 3, 5, 8).

Reviews the law's treatment of race and identity with respect to two groups of color, Latinos and Native Americans. Shows inconsistencies and dubious factual bases for certain common social beliefs, such as that Latinos/as are easily able to assimilate into mainstream society. Shows that the law's treatment of these groups is incoherent, suffering from rigidity and the assumption that race is biological and fixed at birth.

Torres, Gerald, Critical Race Theory: The Decline of the Universalist Ideal and the Hope of Plural Justice-Some Observations and Questions of an Emerging Phenomenon, 75 Minn. L. Rev. 993 (1991). (Themes $1,10)$.

Discusses cultural nationalist movements, comparing them to political interest group politics. Argues that the two should not be confused and that the former embraces a broader, more vital way of thinking about social life. Argues that theorists who promote pluralism and postmodern approaches should reinterpret what they are doing to incorporate cultural difference without falling prey to the notion of one universalizing, totalizing system of justice. 
Torres, Gerald, Local Knowledge, Local Color: Critical Legal Studies and the Law of Race Relations, 25 San Diego L. Rev. 1043 (1988). (Themes 1, 10).

Analyzes Supreme Court opinions to show how the Anglo majority frequently fails to understand its oppression of cultures of color. Argues for a "new cultural pluralism" that avoids these defects and examines more sympathetically the relationships between law, coercion, and culture or local law.

Torres, Rodolfo D. \& ChorSwang Ngin, Racialized Boundaries, Class Relations, and Cultural Politics: The Asian-American and Latino Experience, in Culture and Difference: Critical Perspectives on the Bicultural Experience in the United States 55 (Antonia Darder ed., 1995). (Themes $1,4,6,8,14$ ).

Argues that continued use of the black/white paradigm perpetuates a simplistic view of race that is incapable of addressing complex, multiple racisms. Shows how racialization of Latinos and Asians is based mainly on color and physical appearance despite the wide range of cultures, languages, religions, and social classes the groups contain. Follows Robert Miles' argument rejecting the use of the terms "race" and "race relations" as ideological categories. Advocates instead use of the term "racialization," and urges more research and comparative studies of racialized groups in the United States. Calls for exploration of class divisions and intra-group relations, including the racialization of Central and Latin Americans by Mexican Americans.

Valdes, Francisco, Diversity and Discrimination in Our Midst: Musings on Constitutional Schizophrenia, Cultural Conflict, and "Interculturalism" at the Threshold of a New Century, 5 St. Thomas L. Rev. 293 (1993). (Themes 1, 5, 6).

Examines how "cross-traditions" of normative liberty/equality and substantive non-liberty/inequality in the United States have evolved at cross purposes to frustrate the achievement of liberty and equality by traditionally subordinated groups. Uncovers ways jurisprudential techniques of analyzing racial, ethnic, gender, sexual orientation, and class-status legal issues contain built-in biases that consistently reproduce (non)liberty/(in)equality. Contrasts two cross-traditions in the law that promote opposite normative visions: the legalistic enterprise, which advances a unicultural ideal, and the humanistic agenda, which stresses multicultural values. Argues instead for an intercultural jurisprudence that transcends the 
constitutional schizophrenia engendered by the cross-traditions of legalism and humanism, thereby fusing unicultural principles with emerging demographic multiculturalism to achieve a fairer result.

Valdes, Francisco, Unpacking Hetero-Patriarchy: Tracing the Conflation of Sex, Gender and Sexual Orientation to its Origins, 8 Yale J.L. \& Human. 161 (1996). (Themes 1, 5, 6, 7).

Traces and critiques the historical conflation of sex, gender, and sexual orientation-a "tautological trinity"-originating in ancient Greek society and culminating in the current androsexist and heterosexist Euro-American system. Notes that the Euro-American system is the only one of its kind to construct gender as if it were an absolute, reducing gender exclusively to sex. Contends that this "regime of compulsory hetero-patriarchy" represents the historical fusion of androsexism and heterosexism, socially privileging masculine, heterosexual men, and more importantly, implying that women and sexual minorities share an identical reform agenda when they do not. Argues that reconsideration of the constitutional value of "non-instrumental" forms of desire and a recognition of the intrinsic social worth of unrestrained intimacy are essential to doctrinal reform, and ultimately to substantive equality itself.

Valle, Victor \& Rodolfo D. Torres, The Idea of Mestizaje and the "Race" Problematic: Racialized Media Discourse in a Post-Fordist Landscape, in Culture and Difference: Critical Perspectives on the Bicultural Experience in the United States 139 (Antonia Darder ed., 1995). (Themes 4, 6, 8, 16).

Examines media coverage of the 1992 South Central Los Angeles riots after the acquittal of police officers who beat Rodney King. Demonstrates how the media asserted narrative authority and conflated the categories "race" and "multiculturalism," implying that the latter fueled the former. Shows also how the media focused on the "foreignness" of Latinos/as and reinforced stereotypes of them as lawless illegal aliens out to ruin the dominant culture, instead of analyzing the socioeconomic causes, including police brutality and unresponsive government, of the riots. Criticizes the categorization of Latinos as a race when they are people of mixed cultures, languages, histories, and classes exemplifying mestizaje. Argues that the Latino/a perspective needs a more nuanced voice in media discourse. 
Villarreal, Carlos, Culture in Lawmaking: A Chicano Perspective, 24 U.C. Davis L. Rev. 1193 (1991). (Themes 1, 3, 6, 10, 15).

Examines how mainstream cnlture in the United States has harmed the Chicano community. Shows that these harms result in Chicanos/as relating to the dominant society in three different ways: assimilation, which has psychological, sociological, and economic repercussions; fragmentation, which forces Chicanos/as to attempt to live in two different worlds, one inside and one outside their cultural heritage; and separation, wherein Chicanos/as isolate themselves from the majority culture. Acknowledging a white-male Protestant bias in tort doctrine, investigates the role of culture in tort lawmaking and promotes pluralism as a way to achieve respect for diversity in law. Cites court decisions that implicitly take cultural values into account, providing protection against discrimination. Advocates a specific tort for discrimination based on ethnicity.

Villarreal, Carlos, Limits on Lawmaking: A Chicano Perspective, $10 \mathrm{St}$. Lonis U. Pub. L. Rev. 65 (1991). (Themes 1, 3, 5, 11, 16).

Examines early case law affecting Chicanos/as in several areas, including land disputes, police confrontations, and immigration, with a view to determining whether formalist or legal-realist approaches afford better justice. Concludes that both approaches have dangers; formalism subordinates minority rights to majoritarian interests, while realism erodes individual rights when the political winds shift. Warns that communities of color should not complacently rest with a court's articnlation of a sought-after right; interests may change in the future, and the rule may erode. Courts proceeding under either approach must constantly remind themselves of the dangers associated with it, while commnnities and litigators of color must engage in coalition-building and pursuit of law's benevolent exercise to protect against tomorrow's whim.

Walsh, Catherine E., Pedagogy and the Struggle for Voice: Issues of Language, Power, and Schooling for Puerto Ricans (1991). (Themes 9, 12).

Examines social and cultural factors that affect the ways Puerto Rican children deal with bilingnalism. Shows how recognition of voice is implicated in the relation between language and power. Recounts the effect of colonialism on Puerto Ricans, examines the tensions and oppositions in language study, analyzes the power and meaning of language, advocates validation of students' voices as 
shaped by their particular experiences, and establishes a border pedagogy.

Words that Wound: Critical Race Theory, Assaultive Speech, and the First Amendment (Mari J. Matsuda et al. eds., 1993). (Themes 1, 3, 4, 5).

Essays on hate speech by Mari Matsuda, Charles Lawrence, Richard Delgado, and Kimberlè Crenshaw that cliscuss the case for legal redress for racial insults and invectives. Argues that words like "spick," "kike," and "nigger" injure democracy, set back the cause of racial justice, and are redressable under the First Amendment. 